\title{
3 The wider Greco-Roman discourse on being human and the idea of a human role in the cosmos
}

In this chapter we offer two broader contextualisations for our analysis of Epictetus as a parallel to Romans. The first is a diachronic survey of important texts that reflect on what it means to be human (section 3.1). The result of this will be to show that the human endowment with reason is a prominent part of a wider Greco-Roman discourse on what it means to be human. This is important because it shows that the traditions we see articulated particularly in Epictetus (chapter 4) are more broadly shared. The second contextualisation focuses on the idea of a human role in the cosmos in Greco-Roman sources (section 3.2). This is important because it (a) helps us to define our notion of a human vocation in conversation with ancient texts (and an important study of Heinemann ${ }^{1}$ ); and it (b) shows the variety of language that is used to express this.

This chapter can be regarded as complementary to our discussion of the def-

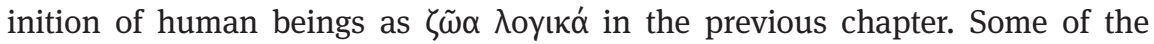
themes which we here encounter as part of our general survey of GrecoRoman reflection on what it means to be human, based mainly on evaluating sources discussed in secondary literature, we have found already in our corpus-based research. This lends support to our claim that broader anthropological reflection is condensated in discourse employing the definition of human beings as rational mortal animals. Most of the passages we discuss in the following contain reason language in a broader sense (for which our list in note 1 of section 1.1

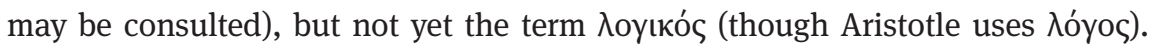
This is because the sources we discuss here are mostly pre-Chrysippean, and as we have shown in section 2.2, the term used in this sense can only reliably be documented since the $3 d$ century BC. But many of the distinctions and ideas, including the contrast with irrational animals ( $\tau \dot{\alpha}$ ó $\lambda \circ \gamma \alpha$ ), are already there.

With a view to Rom 12.1-2, we may also point out that since Rom $12.1 \mathrm{~b}$ refers

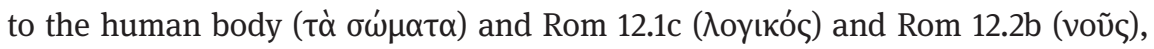
as we shall argue, to human reason, we will be particularly interested in the discussion of the relation of the human body and mind in the following texts. Furthermore, because Rom 12.1-2 serves an important transitional function in the letter (as we shall argue in chapter 7), and hence is linked to other themes dis-

1 Heinemann 1926.

Ә OpenAccess. () 2021 Simon Dürr, published by De Gruyter. (cc) BY-NC-ND This work is licensed under the Creative Commons Attribution-NonCommercial-NoDerivatives 4.0 International License.

https://doi.org/10.1515/9783110750560-004 
cussed before and after in Romans, we will also be interested in finding resonances between other parts of Romans and the main themes that emerge in ancient reflection on what it means to be human, particularly where they focus on the human endowment with reason, and how it is the basis of what humans can and should be doing in the cosmos.

\subsection{Greco-Roman anthropological discourse and the role of human reason}

In this section, we discuss important contributions to ancient anthropological discourse, adhering mainly to the mostly chronological ordering of the material prevalent in the classical studies that have covered the ground before. ${ }^{2}$ This provides the larger context for the prominent role of human reason within discussions of what it means to be human, which is later expressed by the term 入oyıкó (as we have seen in section 2.2). At some points we will directly point out the relevance for our study of Paul.

\subsubsection{Early Greek literature: The contrast with the gods}

The earliest Greek reflection about humans sees them, as a group, in contrast to the gods:

2 An outstanding survey to which many later works refer back is Landmann 1962 (cf. the English translation Landmann 1979), with a comprehensive bibliography of earlier works in philosophical anthropology. Much of the same material, and sometimes more, though with a specific focus on animals and the comparison and contrast between humans and animals, can be found in Dierauer 1977, who critically examines many of the sources from a philological point of view. The work of Sorabji 1993, with a particular interest in ancient precursors to modern ethical stances, offers additional material. For ancient debates on animal rationality cf. also Newmyer 2005, 2011, 2014; for Philo of Alexandria's debate with Tiberius Alexander on animal rationality see Terian 1981 and Niehoff 2018, $70-74$, who points out that "the topic of the animals' rationality was hotly debated in Rome” (73). Valuable summaries of Greco-Roman philosophical anthropology with copious references to Greco-Roman sources can be found in Hügli 1980 and in Rapp and Horn 2001 (where the focus is on human reason). The contributions in Moore 2014, inspired by the work of Derrida, seek to problematise the ancient distinctions between animal, divine and human. Insofar as they evaluate them from a modern standpoint (cf. e.g. Buell 2014, 66), they are not directly relevant for our purpose of historical description of ancient thought. 


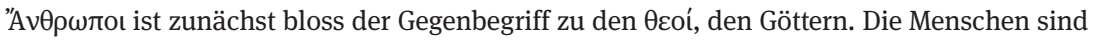
jene Wesen, die ihren Wohnsitz nicht im Himmel, sondern ... auf der Erde haben, sie sind die Sterblichen, die Götter dagegen die Unsterblichen. ${ }^{3}$

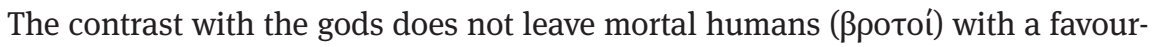
able verdict, a point that is aptly reflected in later Greek comedy:

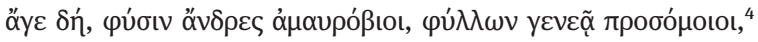

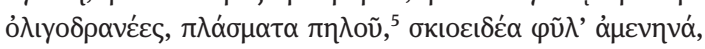

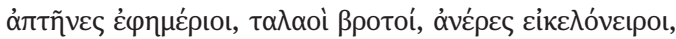

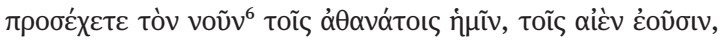

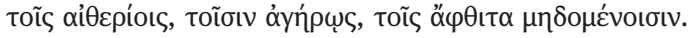

Hark, you whose lives are dark and dank, who fall like leaves in autumn, You puny beings, formed from clay, you shadowy, feeble peoples, You wingless creatures-of-a-day, pathetic dreamlike humans, Pay close attention to our words, for we are true immortals, Who live in air and never age, whose thoughts will never wither. (Aristophanes, Av. 685-689) ${ }^{7}$

Humans are not only short lived ephemerals, shadowy and dream-like, however. In contrast to the blissful gods, they are full of sorrow and suffering ( $\alpha \lambda \lambda \alpha o$ í), ${ }^{8}$ perhaps even most of all creatures:

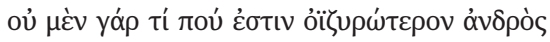

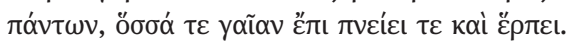

For truly there is nothing, I think, more miserable than man among all things that breathe and move on earth. (Homer, Il. 17.446-447) ${ }^{9}$

The archaic pessimism is perhaps given its most stark expression in the preference of not being born at all, and if born, to die as early as possible:

3 Hügli 1980, 1062, with reference to the etymological study of Seiler 1953, 228.

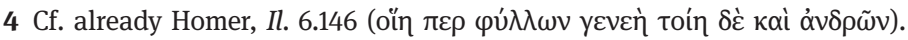

5 This is the earliest Greek reference to the widespread motif of humans' being formed from clay or earth, on which see Dunbar 1997, 429-430. Cf. Rom 9.21.

6 On the use of voũ in phrases, see Strüder 2005, 197-198.

7 Transl. Stephen Halliwell. These verses are cited by Plutarch, Am. prol. 496B (applied to new-

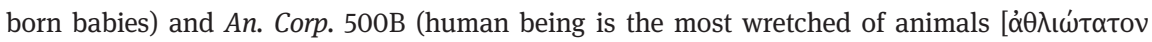
$\zeta \omega \omega v])$.

8 The word form $\tau \alpha \lambda \alpha o$ is singular in classical Greek (cf. Dunbar 1997, 431). Cf. also the composite word $\tau \alpha \lambda \alpha i ́ \pi \omega \rho \circ \varsigma$ in Rom 7.24.

9 Transl. A. T. Murray and William F. Wyatt. 


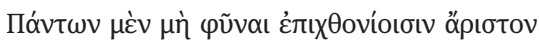

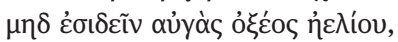

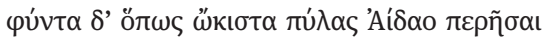

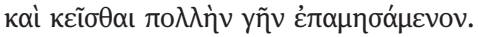

It is best of all for mortals not to be born and not to look upon the rays of the piercing sun, but once born it is best to pass the gates of Hades as quickly as possible and to lie under a large heap of earth. (Theognis, 1.425) ${ }^{10}$

\subsubsection{Hesiod: Justice distinguishes from animals}

Once humans are no longer seen primarily in contrast with the gods, however, and begin to be differentiated from the cosmos, ${ }^{11}$ their distinctive features come into view, especially in contrast with animals.

The first attestation in Greek literature for a categorial distinction between humans and animals is found in the 8th century poet Hesiod. ${ }^{12}$ In an appeal to his brother Perses, with whom he is in a dispute about their inheritance, Hesiod depicts the human sphere as falling in the purview of personified $\Delta$ ík (Justice), which distinguishes it from the sphere of animals: ${ }^{13}$

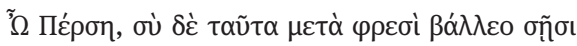

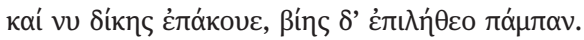

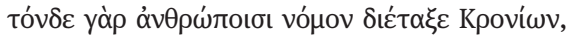

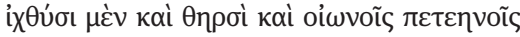

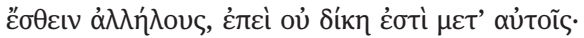

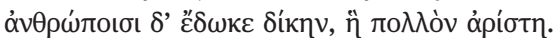

Perses, lay these things in your heart and give heed to Justice, and put violence entirely out of your mind. This is the law that Cronus' son has established for human beings: that fish and beasts and winged birds eat one another, since Justice is not among them; but to human beings he has given Justice, which is the best by far. (Hesiod, Op. 274-279) ${ }^{14}$

The difference between humans and animals presupposed here is based not on superficial appearance, but consists in a way of life based on law and justice. ${ }^{15}$ Interestingly, humankind's association with Justice ( $\Delta$ íkn), as reflected in human

10 Transl. Douglas E. Gerber.

11 For the early natural philosophers see Landmann 1979, 17-23.

12 Cf. Dierauer 1977, 15.

13 The animals are addressed in a summary phrase, as there is not yet a term that takes animals as a category into view, see Dierauer 1977, 6-7.

14 Transl. Glenn W. Most.

15 Cf. Dierauer 1977, 16. 
law-giving, is the ground for an ethical appeal to heed justice and to turn away from violence (ßíns). ${ }^{16}$

With a view to Romans, it is noteworthy that justice as a possibility is mentioned in Hesiod as something that marks humanness.

\title{
3.1.3 Alcmaeon: Humans alone are able to understand
}

While for Hesiod legal justice was constitutive for the difference between humans and animals, the 5th century BC philosopher Alcmaeon, for the first time in extant Greek literature, claims a unique noetic property for humans, which from that point on becomes part of the descriptive arsenal employed for humans. ${ }^{17}$ The contrast with the gods is still in view; they alone can have clarity, while humans must judge from signs:

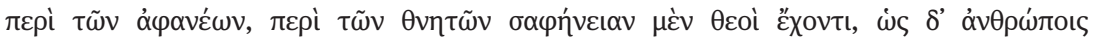

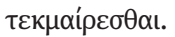

Of things invisible, as of mortal things, only the gods have certain knowledge; but to us, as humans, only inference from evidence is possible. ${ }^{18}$

As reported by Theophrastus, however, Alcmaeon distinguishes humans clearly from the non-human sphere as well, by attributing to them understanding, and not only sense perception:

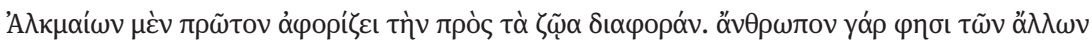

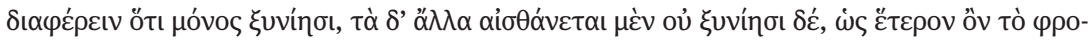

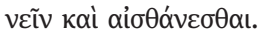

Alcmaeon begins by determining the difference with regard to animals. For he says that a human being differs from the others because he is the only one that understands, while the others perceive but do not understand, since he considers that thinking and perceiving differ from one another. ${ }^{19}$
\end{abstract}

16 See Dierauer 1977, 16. For a recent discussion of the protreptic nature of Hesiod's Opera et dies, see Clay 2009 (with an interesting focus on $\dot{\alpha} \rho \tau \tau$ ' and the allegory of the two paths [83], cf. Hesiod, Op. 289-292).

17 Hügli 1980, 1063.

18 DK 24.B.1 (= DL 8.83). Transl. R. D. Hicks (adapted).

19 Theophrastus, Sens. 25 (cf. DK 24.B.1a). Transl. André Laks and Glenn W. Most. 
Alcmaeon is therefore the first to express what it means to be human in terms of what is later associated with human reason, notions that increasingly gain wide currency.

\subsubsection{Protagoras: Humans as cultural beings}

The comparison of humans with certain animals, however, also exposes humans' bodily weakness and inferiority. The problem and a compensating solution can be seen particularly well in the myth put forth by Protagoras in Plato's dialogue under the same name (Prot. 320c-322d), ${ }^{20}$ which in all probability contains ideas attributable to the 5th century sophist. ${ }^{21}$ The brothers Prometheus and Epimetheus are given the task of equipping the mortal creatures with the

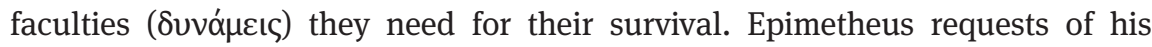
more intelligent brother the opportunity to endow the creatures first and is granted his wish. Some animals are given strength, others speed, yet others become armed or furnished with other devices - all with the aim of a proper balance conducive to the preservation of animalkind. Furthermore, they receive, as means of protection and shelter, thick hair and hides, among other things (320e-321b). There is just one problem with Epimetheus' liberal distribution:

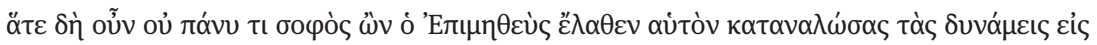

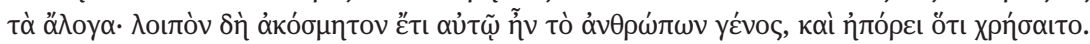

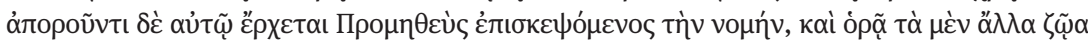

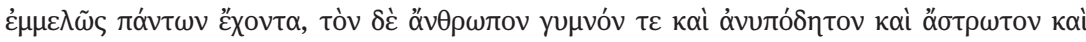

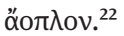

But Epimetheus was not very wise, and he absentmindedly used up all the powers and abilities on the nonreasoning animals; he was left with the human race, completely unequipped. While he was floundering about at a loss, Prometheus arrived to inspect the distribution and saw that while the other animals were well provided with everything, the human race was naked, unshod, unbedded, and unarmed. (Plato, Prot. 321b-c) ${ }^{23}$

Epimetheus, eponymously lacking foresight, forgot about humans, who are consequently naked, without shoes, without bed, without natural weapons. Prome-

20 For a recent commentary, see Denyer 2008.

21 Cf. Guthrie 1957, 140 n. 8; Dierauer 1977, 37.

22 Cf. the alliteration that results from the string of adjectives with alpha privativum applied to

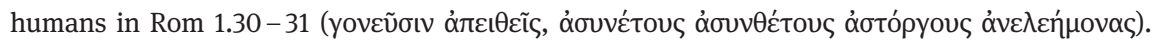
23 Transl. of Plato's Protagoras used in this section: Stanley Lombardo and Karen Bell (in Cooper and Hutchinson 1997). 
theus, in order to save humankind, resorts to stealing both divine technology and - famously - fire, and hands it to humans as a gift:

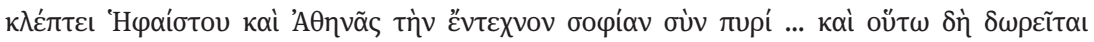
$\dot{\alpha} v \theta \rho \omega ́ \pi \omega$.

[Prometheus] stole from Hephaestus and Athena wisdom in the practical arts together with fire ... and gave them outright to the human race. (Plato, Prot. 321d)

While he had thereby procured for humans the skills necessary for life (тìv ...

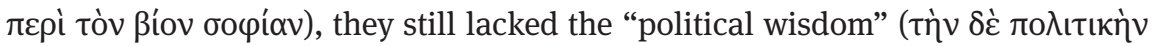

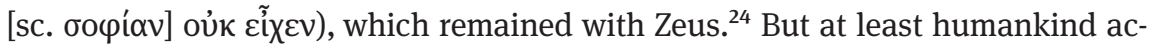
quired the cultural craftiness that compensates for its otherwise scarce endowment with various cultural goods (dwellings, clothes, shoes, agriculture):

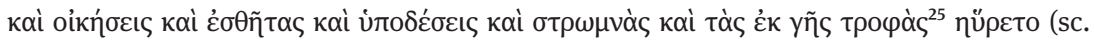

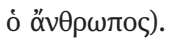

[And they] invented houses, clothes, shoes, and blankets, and were nourished by food from the earth. (Plato, Prot. 322a)

Despite their now being able to provide for themselves, humans were still de-

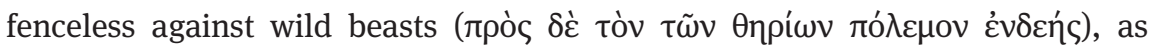
they did not yet live in cities (

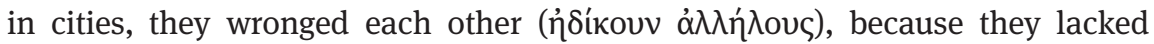

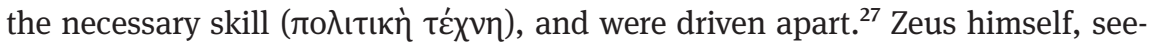
ing that otherwise humanity would become extinct, finally sends a sense of ret-

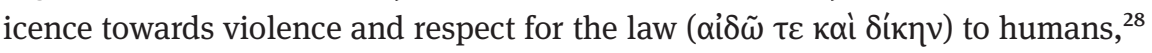

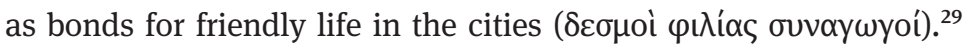

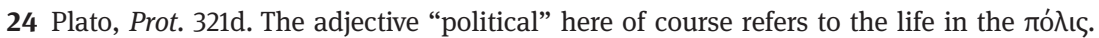

25 Strictly speaking, agriculture would be associated with Demeter, cf. Landmann 1979, 41.

26 Plato, Prot. 322b.

27 Plato, Prot. 322c.

28 To be dispensed in "democratic fashion," cf. Plato, Prot. 322d. This element may be a "po-

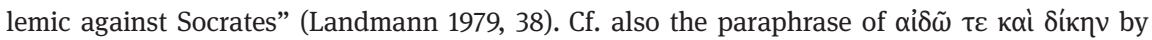

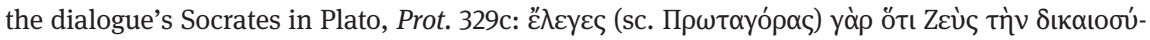

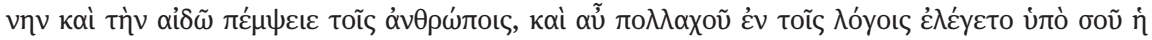

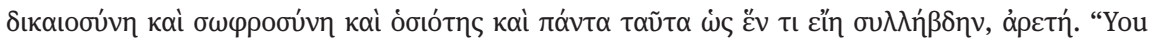
said that Zeus sent justice and a sense of shame to the human race. You also said, at many points in your speech, that justice and temperance and piety and all these things were somehow collectively one thing: virtue". Apparently the more archaic word díkn, suitable for the myth, is

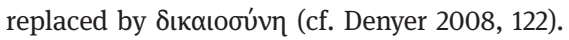

29 Plato, Prot. 322c. 
What is set forth in this myth, then, is this view: humans are distinct from all other animals by their cultural goods and their technology that compensate for their relative bodily inferiority. In addition, they can join themselves to live in cities, which requires a sense of justice.

In the myth, the cultural goods originate in the divine sphere and need to be brought to humans. By contrast, for thinkers like Xenophanes, the sharp critic of anthropomorphism of any stripe, ${ }^{30}$ humans figure them out gradually for themselves:

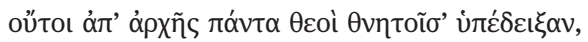

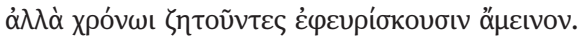

The gods have not indicated all things to mortals from the beginning, But in time, by searching, they find something more that is better. ${ }^{31}$

Up to this point, we have omitted two important characteristics attributed to humans in Protagoras' myth, namely articulate language and recognition of the gods, leading to cultic veneration. These two are much more than mere compensation for bodily inferiority by cultural goods (Protagoras' theme). Rather, they elevate humans above the other creatures and associate them with the divine sphere:

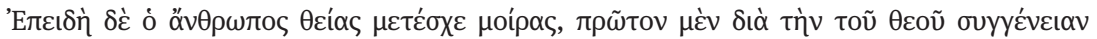

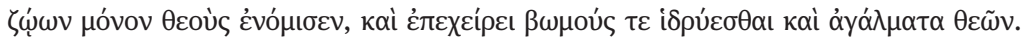

It is because humans had a share of the divine dispensation ${ }^{32}$ that they alone among animals worshipped the gods, with whom they had a kind of kinship, and erected altars and sacred images. (Plato, Prot. 322a)

Mention of religion as a distinctive cultural good for humans seems to sit oddly with Protagoras, the man famous for his homo-mensura statement, which epitomises the turn to human independence from the gods in the realm of knowledge. ${ }^{33}$ The fact that in Plato's rendering of the myth both language and religion are mentioned at a point where they seem to cause an "ugly breach of the context", because they do not fit the scenario of humans as "deprived" beings, may

30 Cf. DK 21.B.11, 12, 14, 15, 16.

31 DK 21.B.18 (= Stobaeus, Ecl. 1.8.2; Flor. 29.41). Transl. André Laks and Glenn W. Most.

32 Namely, the technology originally reserved for the gods.

33 For the homo-mensura statement, which Plato's Socrates then criticises, see Plato, Theaet.

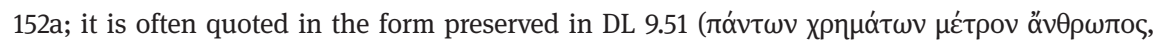

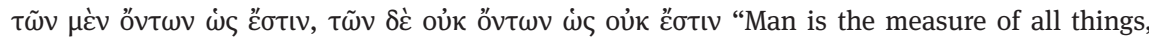
of things that are that they are, and of things that are not that they are not” [transl. R. D. Hicks]). 
point to the influence of earlier, already established traditions, in which needy humanity receives divine gifts, which had to be included. ${ }^{34}$ The elements in Protagoras' myth which do seem to be in line with the Greek sophists' thesis of human self-creation ${ }^{35}$ point to the factor of human creativity which shapes their way of being, both in the domains of knowledge and culture, as Landmann observes:

Just as ... man does not accept external nature as a pre-given but shapes it by his own action in knowledge, so ... his own nature is also not finished from the first but is perfected by subsequently added factors, many of which stem from his own mind. ${ }^{36}$

Thus for the sophists what counts as distinctively human is their cultural production, which is based on the human mind.

\subsubsection{Sophocles: Skilful rule over animals and clever solutions to future problems}

The theme of human resourcefulness and skill in contrast to animals was a prominent part of reflections about humans, well beyond the sophists' circles, as evidenced by the traditions poetically cast into a choral song of Sophocles'

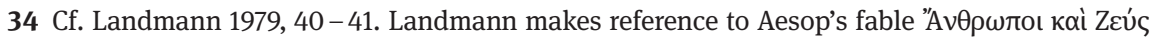
(no. 57 in Chambry 1927, 28). The basic scenario is nearly identical, the gift bestowed is reason:

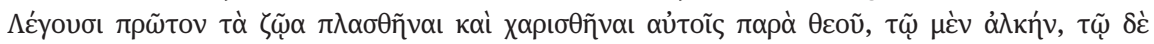

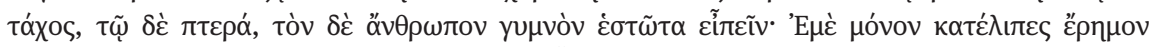

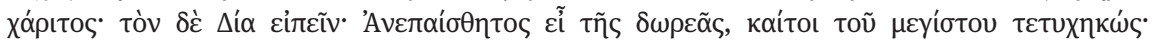

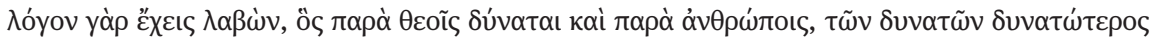

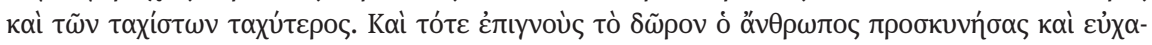

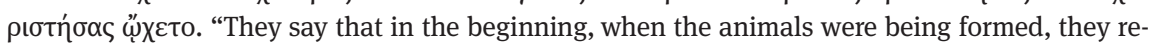
ceived their endowments from Zeus. To some he gave strength, and to some speed, and to others wings. Man, however, was still naked so he said to Zeus, 'I am the only one that you have left without a gift.' Zeus replied, 'You are unaware of the gift you have obtained, but it is the greatest gift of all: you have received the gift of speech and the ability to reason, which has power both among the gods and among mortals; it is stronger than the strong and swifter than the swift.' Man then recognized the gift he had been given and bowed down before Zeus, offering him thanks" (transl. Laura Gibbs). The fact that a fable expresses such motif combinations shows that such ideas were widespread.

35 Hügli 1980, 1063 (“Selbstschöpfung des Menschen”).

36 Landmann 1979, 37-38. 
Antigone. ${ }^{37}$ Humans are characterised from the start by reference to the doubleedged word $\delta \varepsilon เ v o ́ v$, which fluctuates between "terrible" and "awe-inspiring":38

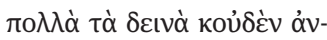

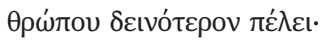

Many things are formidable, and none more formidable than man $!^{39}$

The theme is developed by enumerating human skills in the domains associated

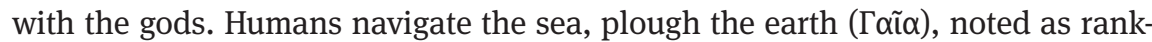
ing among the highest of the gods ${ }^{40}$ with the aid of horses. ${ }^{41}$ They even reach into the sky to the "light-minded" birds; ${ }^{42}$ by their skilful cleverness ( $е р \iota \varphi \rho \alpha-$

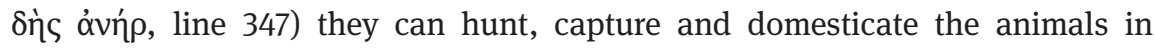
any domain, as they prevail over beasts and rule: ${ }^{43}$

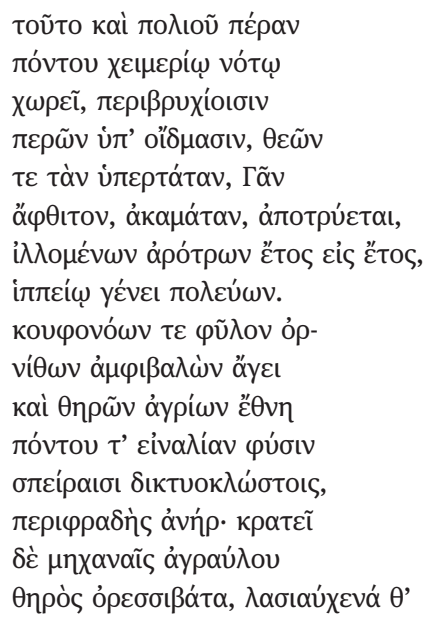

37 Sophocles, Ant. 332-375, in the following quoted by lines only. For a recent commentary see Griffith 1999. Griffith notes that "this is perhaps the most celebrated song in Greek tragedy (often referred to as the 'Ode to man')" (179).

38 On the deliberate multivalence of $\delta \varepsilon$ เvóv see Griffith 1999, 185.

39 332-333. Transl. Hugh Lloyd-Jones (here and below).

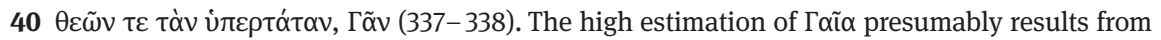
her being the "oldest" (cf. Griffith 1999, 186).

$41334-341$.

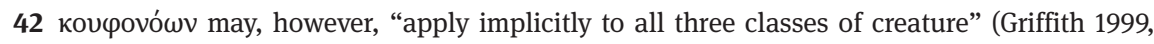
186).

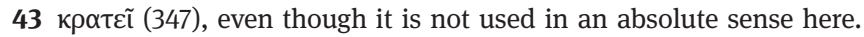




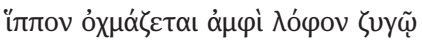

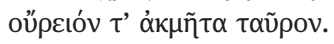

He crosses the gray sea beneath the winter wind, passing beneath the surges that surround him; and he wears away the highest of the gods, Earth, immortal and unwearying, as his ploughs go back and forth from year to year, turning the soil with the aid of the breed of horses. And he captures the tribe of thoughtless birds and the races of wild beasts and the watery brood of the sea, catching them in the woven coils of nets, man the skilful. And he contrives to overcome the beast that roams the mountain, and tames the shaggymaned horse and the untiring mountain bull, putting a yoke about their necks. ${ }^{44}$

The distinctive features of humanity, by which they dominate the initially seemingly better adapted species, are then elaborated by reference to language and thought, which are presented as something to be learned. In addition, the temperament required for living in cities, and housing technology, are mentioned as acquired skills of humans who always find a way out, ${ }^{45}$ as they can come up with solutions to any future problems, with one exception. But while they cannot escape death, they can figure out by their joint thinking ${ }^{46}$ cures for sicknesses for which it seems impossible to find a clever solution:

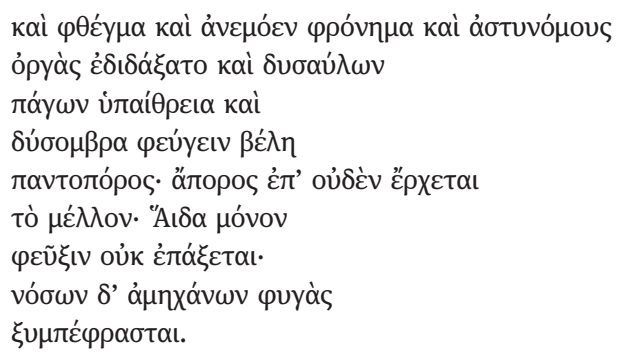

And he has learned speech and wind-swift thought and the temper that rules cities, and how to escape the exposure of the inhospitable hills and the sharp arrows of the rain, all-resourceful; he meets nothing in the future without resource; only from Hades shall he apply no means of flight; and he has contrived escape from desperate maladies. ${ }^{47}$

The praise of human ingenuity then takes on a more sombre tone, as the ambiguity of human reason (in that it can be used both for good and for evil) comes to the fore, in anticipation of the wider narrative context of the tragedy: ${ }^{48}$

$44342-352$.

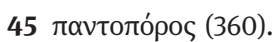

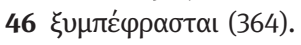

$47355-364$.

48 For a convincing analysis that extends to line 375, see Landmann 1979, 47. 


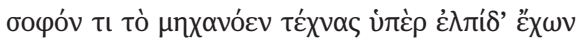

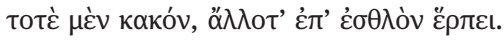

Skilful beyond hope is the contrivance of his art, and he advances sometimes to evil, at other times to good. ${ }^{49}$

Common to many of the traditions we have discussed so far is the human bodily inferiority to many animals. This theme was given memorable expression in the topos of stepmother nature, such as it is preserved, for instance, in Pliny the Elder's Naturalis Historia 7.1-5, probably the most complete list of human shortcomings in comparison with animals in antiquity. ${ }^{50}$ These shortcomings are the cruel price for nature's gift of all the other benefits which exist for the sake of humans, who are assigned the first place:

Principium iure tribuetur homini, cuius causa videtur cuncta alia genuisse natura magna, saeva mercede contra tanta sua munera, ut non sit satis aestimare, parens melior homini an tristior noverca fueri.

The first place will rightly be assigned to humankind, for whose sake great Nature appears to have created all other things - though she asks a cruel price for all her generous gifts, making it hardly possible to judge whether she has been more a kind parent to humankind or more a harsh stepmother. (Pliny the Elder, Nat. 7.1-2) ${ }^{51}$

\subsubsection{Xenophon's Socrates: The human body and mind excel in their combination}

One of the first firmly to resist the view that humans' bodily equipment is to be considered as inferior to that of animals is Xenophon's Socrates in the Memorabilia. ${ }^{52}$ Before we come to the crucial passage (1.4.11-14), however, it is worth looking at its wider context with its teleological perspective. ${ }^{53}$

49 365-366. Cf. similarly Plato, Leg. 766a, quoted below.

50 A concise overview of many human distinctives in contrast to animals in Greco-Roman literature is given in Sorabji 1993, 89-93. Pliny, of course, assembles and collects many earlier traditions in his encyclopaedic efforts. For a recent commentary on book 7, see Beagon 2005.

51 Transl. H. Rackham (adapted).

52 Xenophon, Mem. 1.4. For several reasons, this passage has sometimes struck interpreters as un-Socratic, and the 5th century philosopher Diogenes of Apollonia was in turn identified as a source by Dickerman 1909, Theiler 1925 and others. Landmann (1979, 48), Dierauer (1977, 47), and Hügli $(1980,1064)$ follow this supposition and present the corresponding anthropological material with reference to Diogenes of Apollonia. In more recent contributions, however, the identification is no longer upheld (see e.g. Sorabji 1993, 90; Marciano 2006, 229 n. 68). For a sharp 
In Xenophon's presentation of the material, a dialogue between Socrates and a certain Aristodemus is adduced as an example for the beneficial effects of Socrates' talking activities. ${ }^{54}$ The dialogue is prompted by Aristodemus' rejection of sacrifice to the gods, prayer, and the use of divination. ${ }^{55}$ Socrates asks Aristodemus for humans that he admires for their wisdom ( $\left.\sigma \circ \varphi^{\prime} \alpha\right)$, and asks again, in response to the list Aristodemus provides (covering literature, ${ }^{56}$ sculpture and painting):

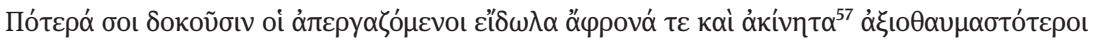

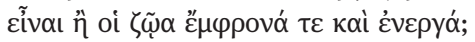

Which do you think deserve greater admiration, the creators of likenesses thoughtless and motionless or the creators of living beings endowed with thought and action (58 $^{58}$

Aristodemus grants the point Socrates is after, provided that it is a result of intelligence and not chance:

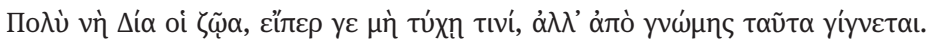

Living beings by far, provided only they are created by design and not mere chance. ${ }^{59}$

The discussion then turns to the characteristic marks from which intelligence can be inferred with some probability. Aristodemus is willing to accept Socrates' premise that a useful purpose is such a mark:

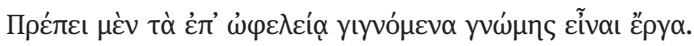

Presumably the creature that serves some useful end is the work of design. ${ }^{60}$

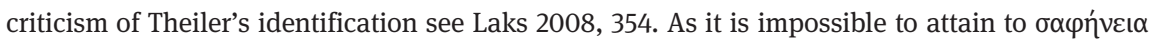
in such matters, and, for our purposes, nothing much hinges on the identification, we shall here present the material with reference to Xenophon's Socrates and the traditions he was possibly reworking (cf. the detailed arguments of McPherran 1994, which support such a stance). For a recent discussion of Xenophon's Socrates as completely different from Plato's see Dorion 2013. See also the discussion in Sedley 2007.

53 This perspective is particularly important in view of Epictetus 1.6 and 1.16 to be discussed in the next chapter.

54 Cf. Xenophon, Mem. 1.4.1.

55 Cf. Xenophon, Mem. 1.4.2.

56 Sophocles is favoured for tragedy.

57 An obvious reference to the sculptures and paintings at least.

58 Xenophon, Mem. 1.4.4. Transl. E. C. Marchant, O. J. Todd, J. Henderson (here and below, adapted).

59 Xenophon, Mem. 1.4.4.

60 Xenophon, Mem. 1.4.4. 
At this point, Socrates can launch into a detailed exposition of the usefulness of the human sense organs, ${ }^{61}$ which serves as evidence that humans have been created for some useful purpose. ${ }^{62}$ Aristodemus admits that living beings appear to be a product of deliberate planning and care, ${ }^{63}$ but goes on to insist that only human artisans and their products can actually be seen:

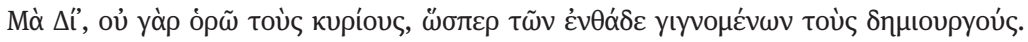

Yes I do; for I don't see these masters, whereas I see the makers of things in this world. ${ }^{64}$

Socrates has a clever reply at his disposal, ${ }^{65}$ and the debate shifts to Aristode-

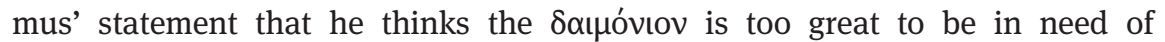
human worship $(\theta \varepsilon \rho \alpha \pi \varepsilon i \alpha)$ :

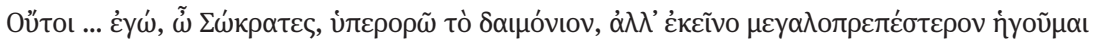

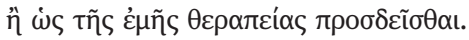

Really, Socrates, I don't despise the divinity but think it too great to need extra service from me. ${ }^{66}$

Socrates is allowed to make a fascinating point, to the effect that the greater the being that offers the worship, the greater the recipient divinity:

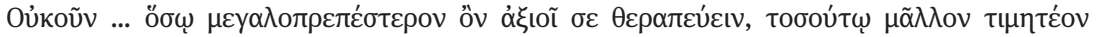
aủtó.

Then the greater the power that deigns to serve you, the more honor it should have. ${ }^{67}$

In consequence, Aristodemus highlights the central question that Xenophon's Socrates then sets out to address in 1.4.11-14. The crucial question is whether

61 Xenophon, Mem. 1.4.5-6.

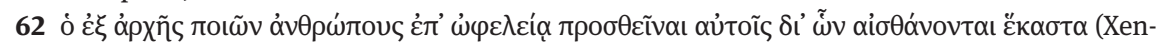
ophon, Mem. 1.4.5).

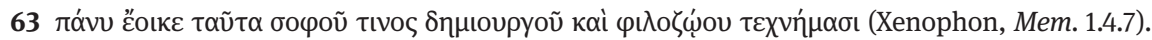

64 Xenophon, Mem. 1.4.9.

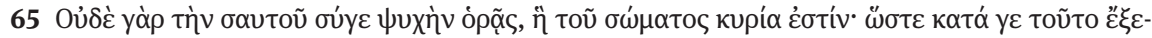

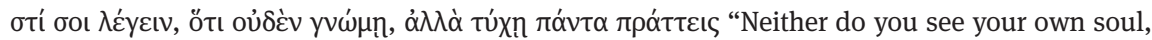
which has mastery of the body; so that, as far as that goes, you may say that you do nothing by design and everything by chance." (Xenophon, Mem. 1.4.9). The noun кupía, by taking up the кupíovৎ in the preceding sentence, makes the comparison more forceful.

66 Xenophon, Mem. 1.4.10.

67 Xenophon, Mem. 1.4.10. 


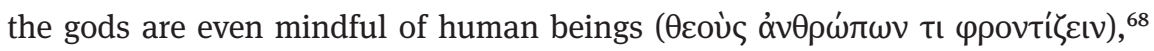
which Socrates answers by pointing to several human distinctives among all other creatures that indicate divine consideration. ${ }^{69}$ The first three $\alpha \dot{v} \theta \rho \omega \dot{\pi} \mathrm{iv} \alpha$ all concern the human body and counter the claims to the effect of its scarce endowment.

First, humans alone were made to stand upright, which gives them a better view of what is ahead and what is above, and protects from some harm:

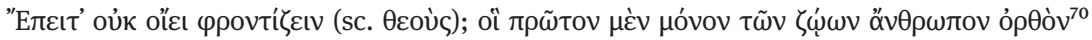

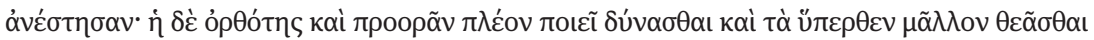

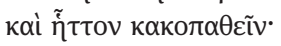

Then do you really think that [the gods] give no thought? In the first place, the human is the only living creature that they have made to stand upright; and the upright position gives him a wider range of vision in front and a better view of things above, and exposes him less to injury. ${ }^{71}$

Second, humans alone are given hands, with which they create most of the things which make them happier than the other creatures:

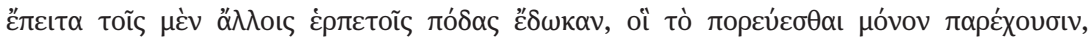

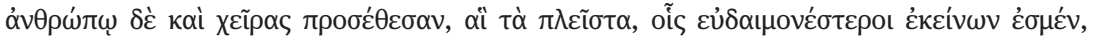

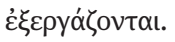

Secondly, to other terrestrial creatures they have given feet that afford only the power of moving, whereas they have endowed humans with hands, which accomplish most of the things that make us more fortunate than the others. ${ }^{72}$

Third, humans alone have a tongue that allows for articulate speech, ${ }^{73}$ and thus communication is no longer restricted to the immediately present, but freed up to express anything they want:

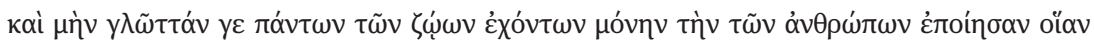

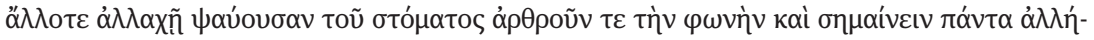
$\lambda$ oıs, $\ddot{\alpha} \beta$ ou $\lambda o ́ \mu \varepsilon \theta \alpha$.

68 Xenophon, Mem. 1.4.11.

69 This question is later associated with an Epicurean position. Cf. our discussion of Epictetus 1.12 in section 4.3.

70 For what it is worth, the basic meaning of o $\rho \theta$ олобєĩv is to walk uprightly, cf. Gal 2.14. Cf.

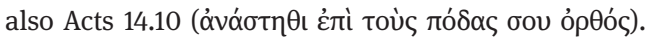

71 Xenophon, Mem. 1.4.11.

72 Xenophon, Mem. 1.4.11.

73 The word $y \lambda \tilde{\omega} \tau \tau \alpha$ already designates speech as well. 
Again, though all creatures have a tongue, the tongue of humans alone has been formed by them to be capable of contact with different parts of the mouth, so as to enable us to articulate the voice and express to one another everything we wish. ${ }^{74}$

The next two distinctives, passing over a note concerning human sexuality, ${ }^{75}$ then concern the superiority of the human soul:

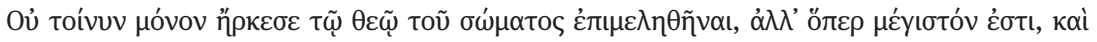

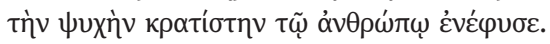

What is more, the deity was not content to care for the body but, most important, also implanted in the human being the soul and made it dominant. ${ }^{76}$

The first reason for the superiority of the human soul is that it alone leads to recognition and worship of the gods:

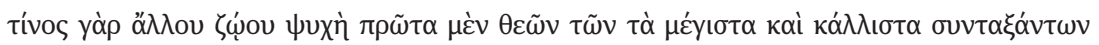

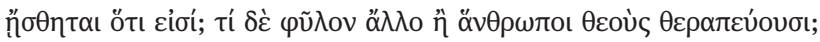

For what other creature's soul, in the first place, has apprehended the existence of gods who set in order the vastness and great beauty of the universe? And what race of living things other than humankind worships gods? ${ }^{77}$

Though Xenophon presents worship of the gods as a distinctive excellence of the human soul, it is possible that Xenophon was reworking traditions in which this element was mentioned already in connection with humans' upright posture,

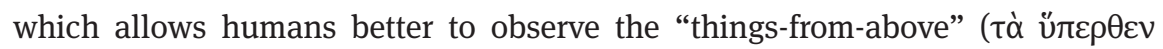
$\mu \tilde{\alpha} \lambda$ ov $\theta \varepsilon \tilde{\alpha} \sigma \theta \alpha \mathrm{l}) .{ }^{78}$ In any case, the motif combination of humans' upward look and their recognition of the divine becomes part and parcel of the GrecoRoman cultural encyclopaedia, ${ }^{79}$ not least in Stoicism. ${ }^{80}$

74 Xenophon, Mem. 1.4.12.

75 Xenophon, Mem. 1.4.12.

76 Xenophon, Mem. 1.4.13.

77 Xenophon, Mem. 1.4.13.

78 For a poetic rendition of the motif of humans looking upward in contrast to the animals bending down, see Ovid, Metam. 1.84-86: pronaque cum spectent animalia cetera terram, / os homini sublime dedit caelumque videre / iussit et erectos ad sidera tollere vultus "And, though all other animals are prone, and fix their gaze upon the earth, he gave to humans an uplifted face and bade them stand erect and turn their eyes to heaven." (Transl. Frank Justus Miller, adapted.) Cf. also Aristotle, Part. An. 656a 4-14, 686a 25-29 (see section 3.1.8) and Philo, Det. 84-85. For a cultural history of the concept up to the present, see Bayertz 2012.

79 Cf. Hügli 1980, 1064.

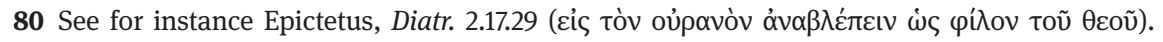


The second reason for the superiority of the human soul is the human mind's ability to procure for human needs, which is explored by listing elements similar to those we have already seen, but adding humans' ability to remember:

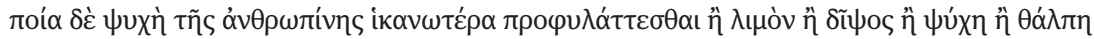

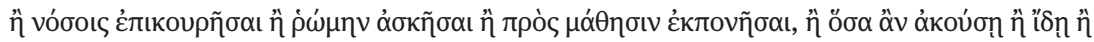

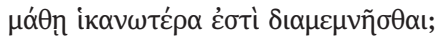

And what soul is more apt than humankind's to make provision against hunger and thirst, cold and heat, to relieve sickness and promote health, to acquire knowledge by toil, and to remember accurately all that is heard, seen, or learned? ${ }^{81}$

The conclusion for Xenophon's Socrates is that humans so far surpass the other creatures both with respect to their body (upright, with hands, articulate tongue), and their soul, as the gods exceed humans:

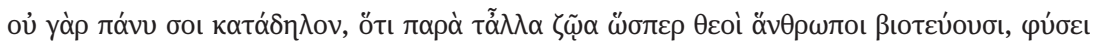

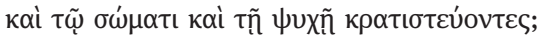

For is it not quite obvious to you that, in comparison with the other animals, humans live like gods, naturally excelling them both in body and in soul? ${ }^{82}$

Moreover, it is the body and the soul's intelligence ( $y v \omega \mu \eta)$, working in tandem and uniquely being fitted for each other, which is constitutive for human excellence:

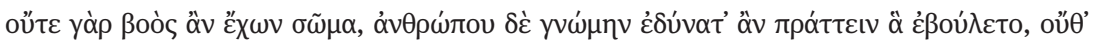

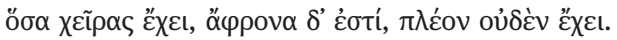

For with a human mind and an ox's body we could not carry out our wishes, nor does the possession of hands without reason provide any advantages. ${ }^{83}$

The human body and mind combining to human excellence is the point at which Xenophon's Socrates concludes his argument for the view that the gods are indeed mindful of human beings: ${ }^{44}$

81 Xenophon, Mem. 1.4.13.

82 Xenophon, Mem. 1.4.14.

83 Xenophon, Mem. 1.4.14.

84 In fact, according to another passage in the Memorabilia (4.4.10), the gods do not only supremely care for human beings, but their care for all the other animals is only a function of their care for humans, for whose sake alone the gods provide the other animals with what they need. Exactly this idea recurs in Epictetus 1.16 (see section 4.4). 


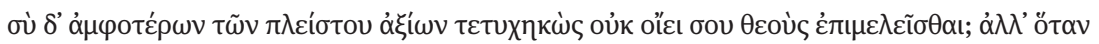

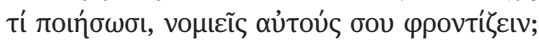

So do you, having received both these priceless gifts, still not think that the gods care about you? What are they to do, to make you believe that you are in their thoughts? ${ }^{85}$

The themes discussed in this passage are of great importance for Epictetus 1.6 and 1.16, where similarly divine care for human beings is demonstrated by appeal to the make-up of the human mind and body (see sections 4.4 and 4.5). Four points sum up our discussion in this section:

First, the human distinctive characteristics, contrasting humans with the other creatures and addressing the question of what it means to be human, are adduced in order to demonstrate divine providence and concern for humanity, and consequently the meaningfulness of prayer and worship of the gods. Second, the greatness of the worshipped is correlated to the kinds of beings that offer worship. Third, what it means to be human is developed with respect to three bodily aspects, each of which becomes associated in the Greco-Roman encyclopaedia with specifically human functions, such as recognition and corresponding worship of the gods, wise stewardship, production of cultural goods, and language. Fourth, the human body with its unique properties and the human mind with its unique excellencies are presented as integrally linked and fitted to one another, and their combination is highlighted as the distinguishing mark of humanness. The role of human reason, closely associated with the body, comes out more explicitly in Aristotle. But before we turn to Aristotle, we will briefly dwell with Plato.

\subsubsection{Plato: Minds placed in the cosmos and souls in conflict}

Plato's dialogues contain several important and influential anthropological reflections. ${ }^{86}$ Among them we find several statements that clearly determine human beings as being different from and preeminent among other animals by virtue of reason. ${ }^{87}$

85 Xenophon, Mem. 1.4.14.

86 For this section, we are relying heavily on Müller 2009, a brief and excellent treatment of Plato's anthropology. Of course, our discussion of Protagoras gave us very much a Platonic portrayal of the sophist. We have quoted Tim. 30b already in section 2.2.3. We will simply refer to Plato and his views, bracketing out the differences between the views presented, for instance, by his Socrates and his own.

87 Cf. Müller 2009, 193. 
For instance, in the Menexenus, ${ }^{88}$ which contains an oration celebrating those fallen in battle by Socrates, we find a statement that attributes understand-

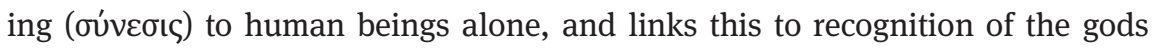

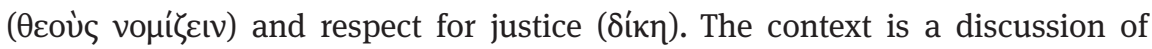
what makes the Attic land praiseworthy. In contrast to other regions, which have caused "creatures of all kind - wild animals and domestic livestock"

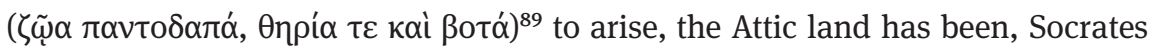

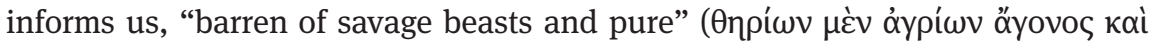
$\kappa \alpha \theta \alpha \rho \dot{\alpha})$, and has chosen the most excellent creature to spring up:

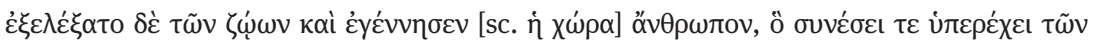

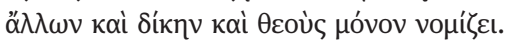

Out of all the animals she [i.e. our land] selected and brought forth the human, the one creature that towers over the others in understanding and alone acknowledges justice and the gods. (Plato, Menex. 237d)

Humans are also distinguished from other animals by virtue of their endowment with reason in the Timaeus. In the final section (90e-92c), the other animals are portrayed as arising from human beings by a gradual descent ( $\mu \varepsilon \tau \varepsilon \rho \rho \cup \theta \mu$ í $\zeta \tau \tau o$ [92d]), according to their increasing deviation from intelligence (voũৎ). The process is then summarised in the following way:

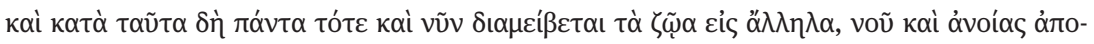

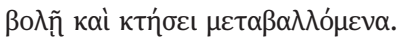

These, then, are the conditions that govern, both then and now, how all the animals exchange their forms, one for the other, and in the process lose or gain intelligence or folly. (Plato, Tim. 92c) ${ }^{90}$

Thus, the specific place of human beings in the cosmos is assigned on the basis of their reason and intelligence (voũc). This also holds true for the other animals. Their various living spaces, from the air, to land, to water correspond with their

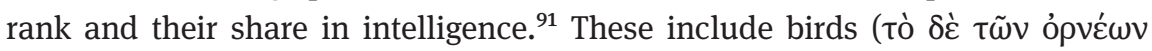

88 The authenticity of the work should not be in doubt (cf. the introductory remarks by John Cooper in Cooper and Hutchinson 1997, 950-951).

89 Transl. of the Menexenus, here and below, by Paul Ryan (in Cooper and Hutchinson 1997), adapted.

90 Transl. of the Timaeus by Donald J. Zeyl (in Cooper and Hutchinson 1997), here and below. 91 The water inhabiting animals are placed lowest in this scala naturae (similar to those encountered in section 2.2) according to share in intelligence, and hence it is seen as appropriate 


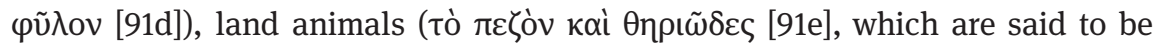

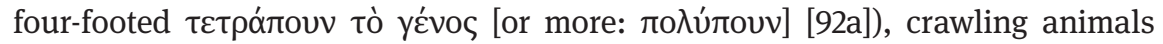

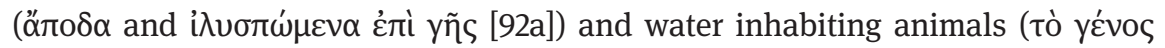

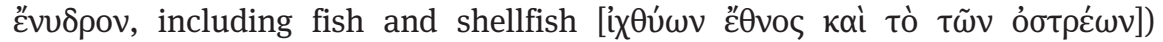
[92b]). These are characterised as increasingly less intelligent or even more stu-

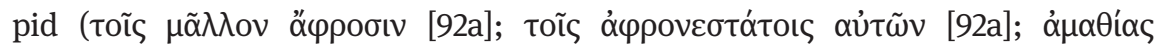

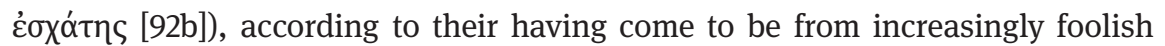

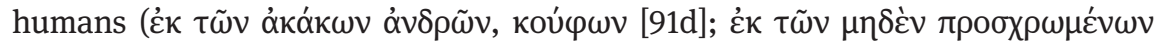

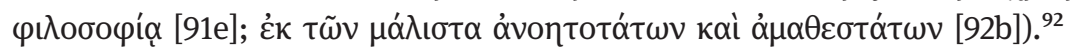

What is particularly clear in this passage is also the association of the upright posture appropriate for human beings, given their endowment with reason and mind. ${ }^{93}$ Because of their endowment with reason and mind, human beings can be characterised by reasoning and close observation, as is suggested by one of the etymological speculations which Plato (in the Cratylus) puts in the mouth of Socrates:

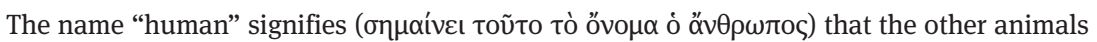
( $\left.\theta \eta p^{\prime} \alpha\right)$ do not investigate or reason about anything they see, nor do they observe anything

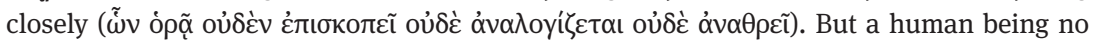

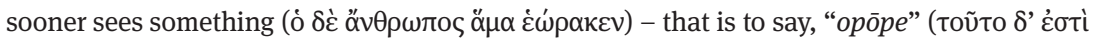

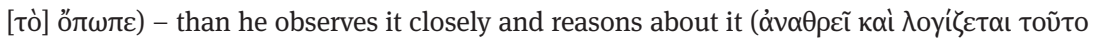
ö ő $\pi \omega \tau \varepsilon v)$. Hence human beings alone among the animals are correctly named "anthrōpos"

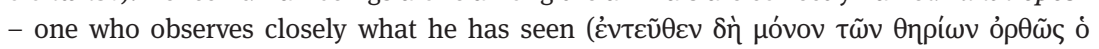

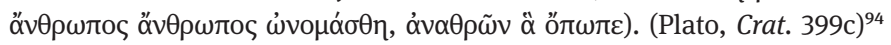

Plato also explicitly reflects on the ambiguity of the human endowment with reason, in that human beings may turn out both ways. In his Leges, humans' potential to use their reasoning abilities for both good and evil is depicted in drastic terms. Human education ${ }^{95}$ is a necessary condition for preventing a lapse into the subhuman sphere:

that their physical placement is lowest: "Their justly due reward for their extreme stupidity is

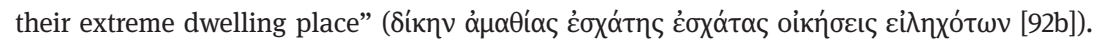

92 This passage may fruitfully be compared to Rom 1.23 (see section 5.2) and also to Epictetus 2.9 (see section 4.2).

93 This is developed with respect to the other animals in Tim. 91e and 92a.

94 Transl. C.D.C. Reeve (in Cooper and Hutchinson 1997).

95 Conceived, admittedly, in the wider context of Plato's peculiar political project. For a comparison with Plato's earlier work see Saunders 1992. A recent commentary on the relevant section of Plato's Leges is Schöpsdau 2003. 


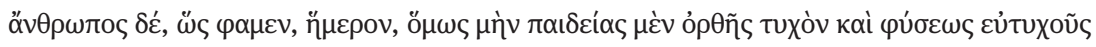

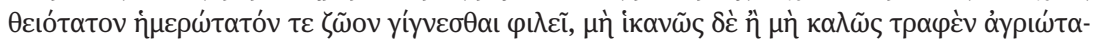

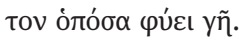

Man is a "tame" animal, as we put it, and of course if he enjoys a good education and happens to have the right natural disposition, he's apt to be a most heavenly and gentle creature; but his upbringing has only to be inadequate or misguided and he'll become the wildest animal on the face of the earth. (Plato, Leg. 766a $)^{96}$

Not least in Plato's reflections on how it is that human beings may behave unjustly he develops various models of how the human soul and body interact. Jörn Müller helpfully distinguished three main models, which can be associated with different works of Plato. A first model, represented for instance in the Phae$d o$, is that of a "kind of numerical substance-dualism" in which the relation between body and soul is contingent. ${ }^{97}$ In such contexts, the body may appear mainly as an obstacle to an unhindered activity of the soul. ${ }^{98}$ Humans are here souls fallen into bodies and exiles from heaven in an alien world. ${ }^{99}$

In a second model, which is found for instance in the fourth book of his Respublica, the conflict between soul and body is made internal to the soul itself. Plato develops a theory of three parts of the soul in Resp. 434d-441c. ${ }^{100}$ The

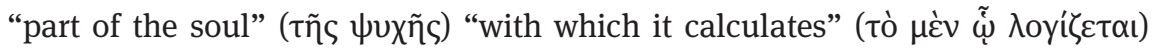
is called the "rational part" (

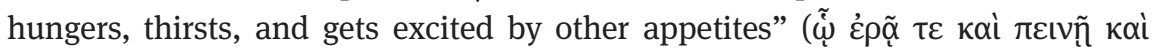

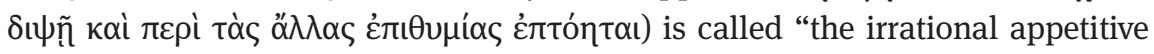

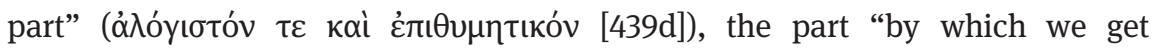

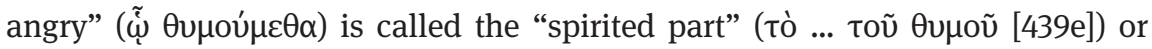

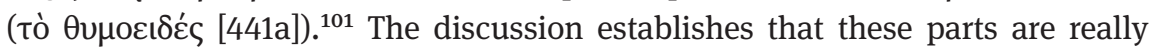
distinct from each other, by considering cases where they are working as opposed forces, such as when one's desire to watch something conflicts with a sense of revulsion (the story of Leontius [439e-440a]). These parts can be op-

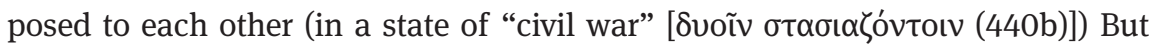
the "spirited" part can also become the "helper" (غ̇лíkoupov) of the rational part, which would be its natural function (441a). In the right state, the rational

96 Transl. Trevor J. Saunders (in Cooper and Hutchinson 1997).

97 Müller 2009, 191 ("eine Art numerischer Substanzendualismus").

98 Famously put in terms of $\sigma \tilde{\omega} \mu \alpha$ (body) and $\sigma \dot{\mu} \mu \alpha$ (tomb) in the Gorgias (493a).

99 Cf. Müller 2009, 192.

100 On Plato's psychology, cf. the succinct statements of Görgemanns 1994, 132-139 and the discussion of Sorabji 1993, 65-67.

101 For the Respublica we use the translation of G. M. A. Grube, revised by C. D. C. Reeve (in Cooper and Hutchinson 1997). 


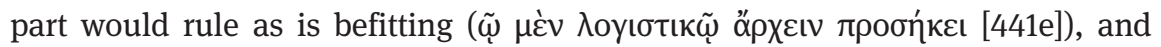
each of the two allies against the "appetitive part" would contribute in its

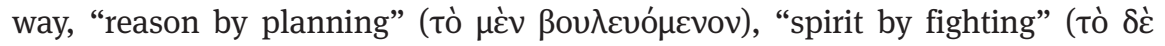
$\pi р о \pi о \lambda \varepsilon \mu о \tilde{v}$ [442b]).

In the ninth book of the Respublica (588b-589d), Plato develops a model of the soul, transparently constructed ${ }^{102}$ with three parts, as "an image of the soul

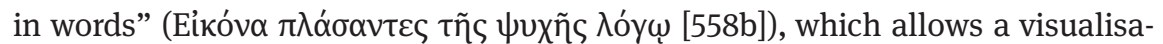
tion of the good soul and the bad soul, and hence can "show" that injustice is harmful for its perpetrator. The first element of the image is a "multicoloured beast with a ring of many heads that can grow and change at will - some

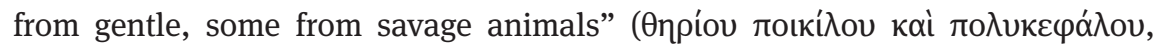

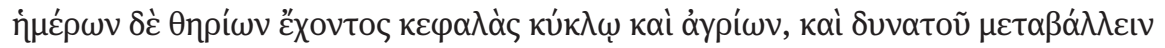

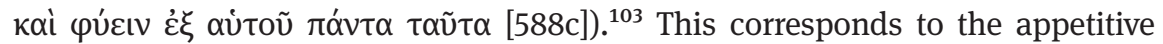

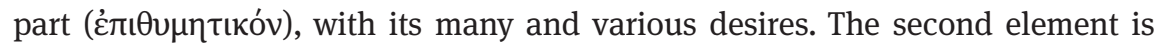

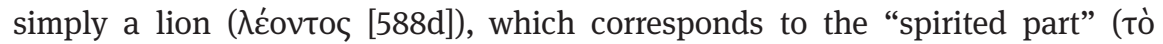

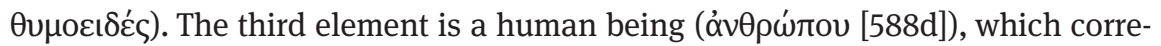

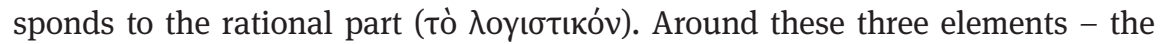

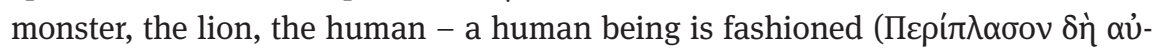

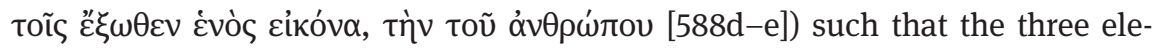
ments are on the inside (and hence the rational part corresponds to "the man inside"104). For an outside observer, it will look like an ordinary, simple being

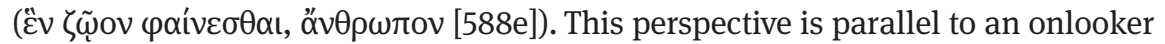
not being able to see the state of the soul of someone committing injustice ( $\alpha \delta$ кعĩ [588e]). But having set up this model, its parameters can be modified to depict the state of wicked and the good soul, and to show that injustice is not profitable (588e). Basically doing injustice is feeding the "multiform beast" (ò

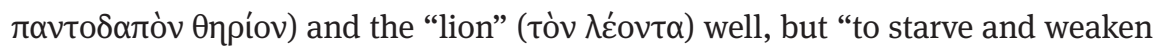

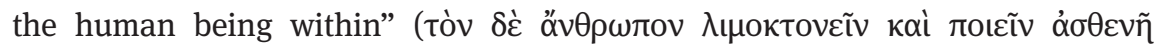
[588e-589a]), and leaving the relation of the parts such that they "bite and

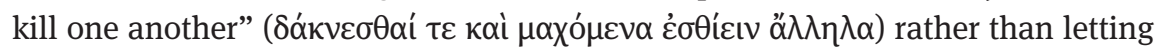
them be "friendly" ( $\varphi$ í $\lambda$ ov) toward each other (589a). By contrast, Plato depicts the good state of the soul as follows:

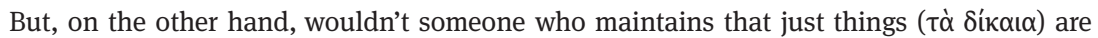

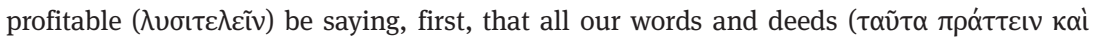

102 Plato does not state in our passage the obvious applications of his image.

103 At 590b, this same part seems to be designated as the "snakelike part" (ó $\varphi \varepsilon \tilde{\omega} \delta \varepsilon \varsigma)$.

104 Cf. on this tradition van Kooten 2008, 358-370. This concept is particularly relevant for Rom 7.22. 


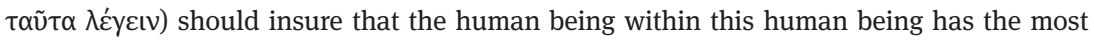

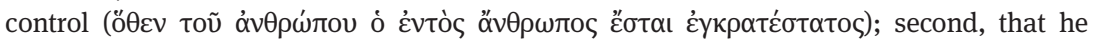

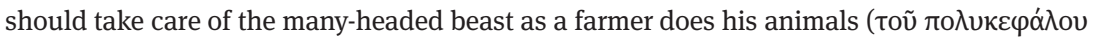

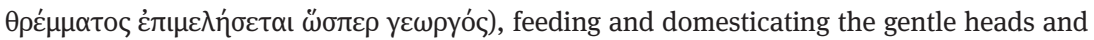

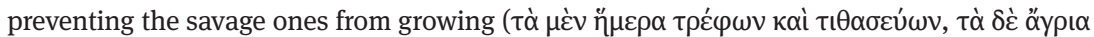

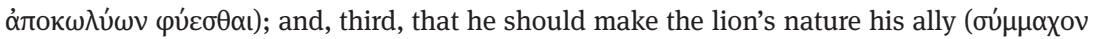

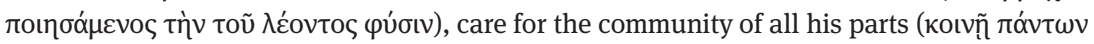

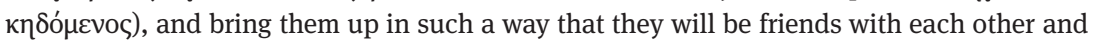

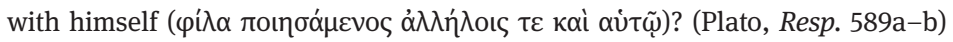

In fine, the "human inside" must rule and the good things ( $\tau \dot{\alpha} \mu \dot{\varepsilon} v \kappa \alpha \lambda \dot{\alpha})$ can be defined as those "that subordinate the beastlike parts of our nature to the

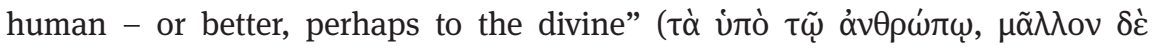

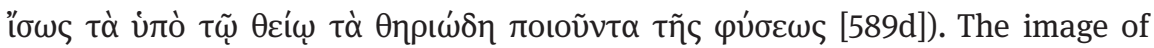
the human being inside, identified with the rational part, is one source for an association of genuine humanness with rationality, as one can see in Philo of Alexandria. ${ }^{105}$ It is also directly important for Epictetus, who draws on this imagery as well to speak about genuine humanness. ${ }^{106}$

The third model, to which Jörn Müller assigns the Philebus and the Timaeus, is described as a "teleological model of cooperation", ${ }^{107}$ in which the body is constituted in such a way as to facilitate intellect in its exercise of control. ${ }^{108}$ These traditions resonate more directly with some of the material we have surveyed in section 2.2 .

We bring our all too brief sketch of some elements of Plato's anthropological reflections to a close with a final quotation from the Respublica, in which Plato describes what happens to the philosopher who has had "his thoughts truly di-

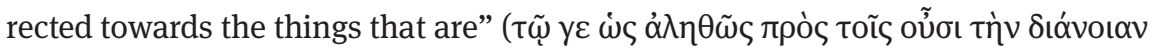

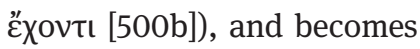

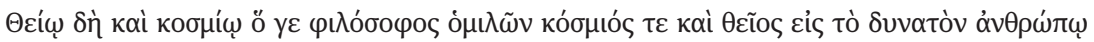

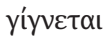

105 Cf. our discussion in 2.2.6.4. Note the reason language (in a broader sense) occurring in the

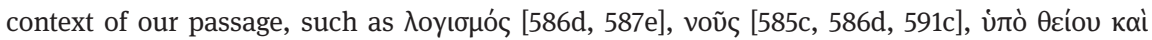

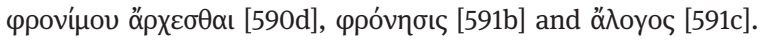

106 Cf. our discussion of Epictetus 2.9 in section 4.2. This is important because Epictetus is in many respects a Platonizing Stoic. On the close relation between Platonism and Stoicism from 100 BC to AD 100, cf. the contributions in Engberg-Pedersen 2017 (especially, for an overview, the introductory essay by Engberg-Pedersen).

107 Müller 2009, 192 (“ein teleologisches Kooperationsmodell”).

108 Müller 2009, 192 (with reference to Johansen 2000). 
by consorting with what is ordered and divine and despite all the slanders around that say otherwise, himself ... as divine and ordered as human beings can. (Plato, Resp. 500d) ${ }^{109}$

With this, we turn to Aristotle.

\subsubsection{Aristotle: All by virtue of reason - humans as supremely "political" beings}

For Aristotle, as for Xenophon's Socrates, the human body and the human soul are "intrinsically interrelated." 110 The same features (upright posture and hands) that distinguish humans from animals are mentioned again. They are now explicitly associated with thinking and reason, a divine part in humans:

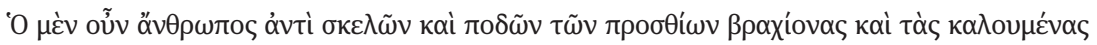

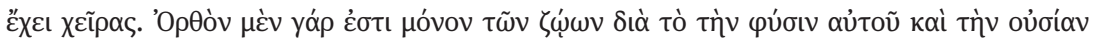

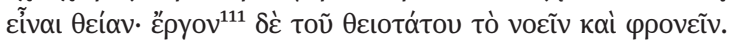

In humans the forelegs and forefeet are replaced by arms and by what we call hands. For of all animals humankind alone stands erect, in accordance with its god-like nature and substance. For it is the function of the god-like to think and to be wise. (Aristotle, Part. An. 686a $25-29)^{112}$

The emphasis on the human's rational nature comes out even stronger in Aristotle's discussion of the human hand. While for Anaxagoras human beings were the most intelligent because of their hands ${ }^{113}$ (a fit of mind to body), Aristotle has it exactly the other way round (a fit of body to mind), on the grounds that nature would not waste a gift on someone who has no use for it:

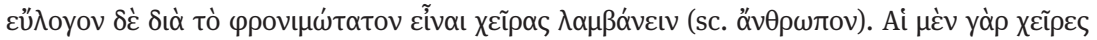

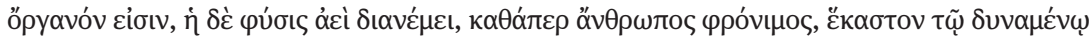
$\chi \rho \tilde{\eta} \sigma \theta \alpha \mathrm{s}$.

109 Cf. for the theme of assimilation to God also Theaet. 176b. For a discussion of the tradition, see van Kooten 2008, 124-199.

110 Landmann 1979, 70.

111 The term ह̌pyov is important to our discussion of Epictetus 1.6 and 1.6 (see chapter 4). 112 Transl. W. Ogle (in Barnes 1995), here and below, adapted. For the divine part in humans see also Part. An. 656a 4-14 and the discussion in Flashar 2014, 325.

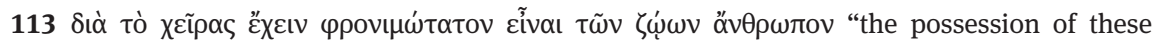
hands is the cause of humans being of all animals the most intelligent" (Aristotle, Part. An. 687a 8-9). 
But it is more rational to suppose that humans have hands because of their superior intelligence. For the hands are instruments, and the invariable plan of nature in distributing the organs is to give each to such animal as can make use of it. (Aristotle, Part. An.687a 9-12)

The same tendency to emphasise reason can be observed with regards to Xenophon's Socrates' third distinctive, namely human language. ${ }^{114}$ In Aristotle's Po-

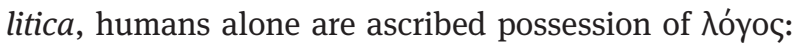

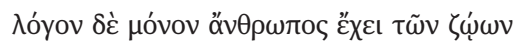

humans alone of the animals possess reason-and-speech. ${ }^{115}$

Here Aristotle means both the endowment with reason and the capacity for language. ${ }^{116}$ Once more, the wider context of Aristotle's statement and the issues he engages are worth exploring with a view to Paul. Not only can one observe in Aristotle an increasing tendency to link the distinctively human traits to reason, ${ }^{117}$ a tendency which some Stoic thinkers will reinforce, but the important social dimension to human existence is given sustained reflection.

114 Cf. Landmann 1979, 71.

115 Aristotle, Pol. 1253a 9-10 (our translation). We have used the cumbersome expression "rea-

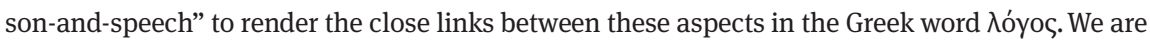
thus following a similar strategy as that adopted by Cicero, Off. 1.50, who renders the distinctive human endowment with a similar circumlocution as "reason and speech" (oratio et ratio). Cf. for this point Inwood 2007, 374 who refers to the "close connection of speech and reason" as a "commonplace”, both in Greek and in Latin. The context of Off. 1.50 is also similar, as human sociability and potential for justice mediated by the common endowment with reason and speech is discussed (as in Aristotle's Politica).

116 Cf. Rapp and Horn 2001, 754 ("Vernunftbesitz" and "Sprachfähigkeit ”). The deliberative aspect is also stressed by Saunders 1995, 70. Even though Flashar 2014, 109 emphasises speech ("Sprache"), his further statements imply that argumentation and discernment is also in view. Pertinent here are also the arguments adduced by Horn 2005, 332, who points to Rhet.

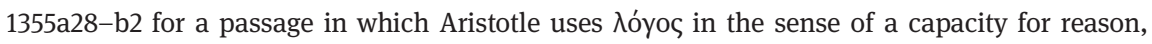
which a rendering with "speech" would not capture (for the same characteristic capacity

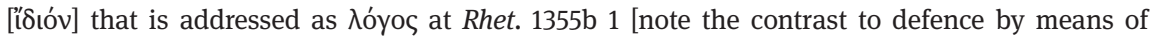

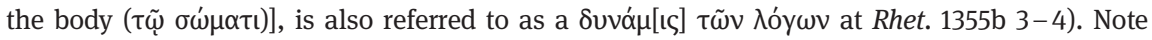
also our remarks below, where we come back to this passage.

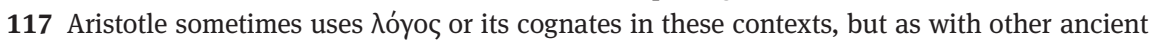
Greco-Roman writers, there is a certain fluidity in the use of expressions that address aspects of human thinking abilities (cf. also Rapp and Horn 2001, 748). He might, for example, refer to hu-

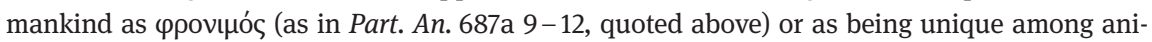

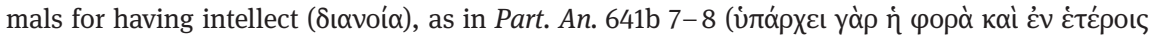

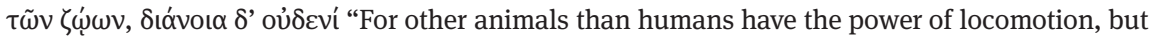




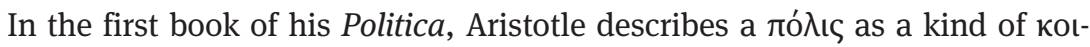

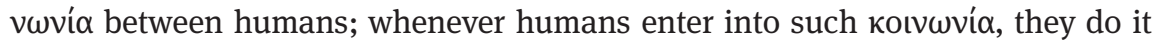

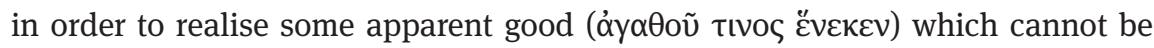

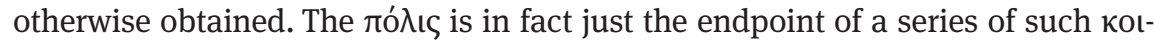
$v \omega v i \alpha$ and comprises the former; the good it realises is accordingly the highest

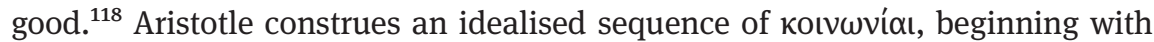
the smallest building blocks out of which his ró

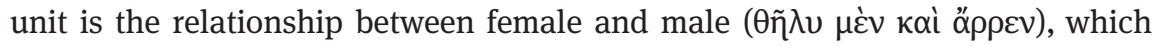
is not unique to humans, but also exists among plants and animals; it aims at

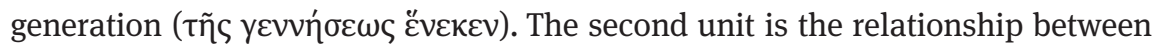
what Aristotle calls a ruler by nature and correspondingly a ruled subject

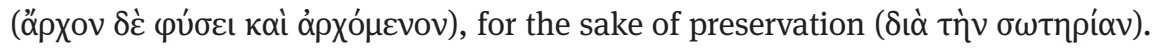
The difference between the "natural" ruler and its subject, even between master and slave, is that the former has the mind to plan for the future and the latter has

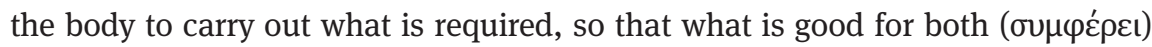
aligns:

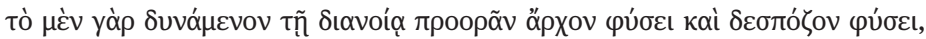

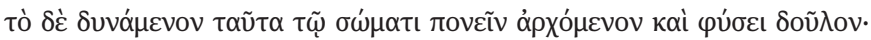

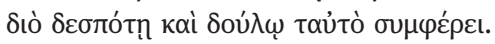

For one that can foresee with his mind is naturally ruler and naturally master, and one that can do these things with his body is subject and naturally a slave; so that master and slave have the same interest. ${ }^{120}$ (Aristotle, Pol. 1252a 31-34)

After a curious sidenote to the effect that "barbarians" are by nature slaves, ${ }^{121}$ and that there are no "natural" rulers among them, ${ }^{122}$ Aristotle sums up the

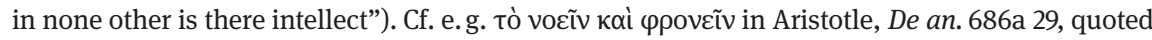
above. See also below.

118 Cf. Aristotle, Pol. 1252a 1-7.

119 Cf. Pol. 1252a 26-1252b 28.

120 Transl. H. Rackham, here and below, adapted.

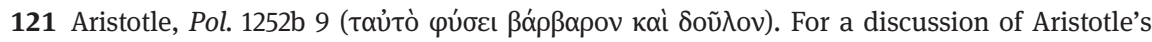
"theory of natural slavery", see Smith 1991, who links Aristotle's views to his accounts of the "relationship of reason to emotion" and "man to beast" (142). Garnsey 1999, 107-127 analyses in critical detail the various analogies Aristotle draws on to construct his theory of the "natural slave" (a "battered shipwreck of a theory" [107]). DuBois 2003, 189-205, problematises the modern philosophical reception of Aristotle's account of slavery and criticises how the "focus on the issue of natural slavery in ... modern readings of Aristotle occludes and misrepresents the ways in which slavery was taken for granted in ancient societies, anachronistically overlaying the racialization of slavery onto the institution in antiquity" (204-205).

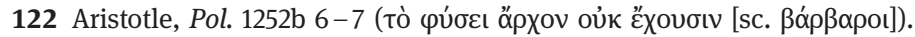




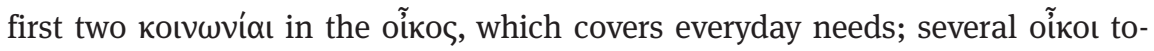
gether in turn join themselves to a $\kappa \omega ́ \mu \eta$, which satisfies what goes beyond the everyday needs. ${ }^{123}$ Aristotle associates kingly rule primarily with the structure of the $\kappa \omega \dot{\mu} \mu$ and even explains the conception of the gods being ruled by a king as an anthropomorphic projection from the rule of a $\kappa \omega \dot{\mu} \mu{ }^{124}$

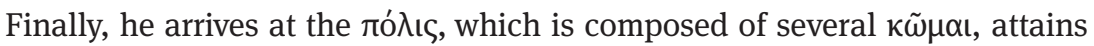

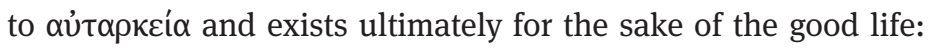

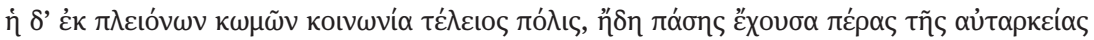

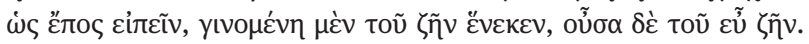

The partnership finally composed of several villages is the city-state; it has at last attained the limit of virtually complete self-sufficiency, and thus, while it comes into existence for the sake of life, it exists for the good life. (Aristotle, Pol. 1252b 27-30.)

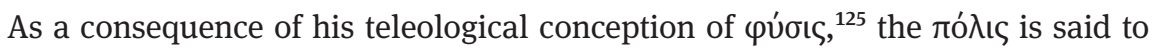
exist by nature, and by implication humans are defined as "political" 126 beings, so much so, that those beings for whom this does not hold true must either be less than fully or far more than human:

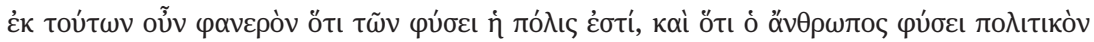

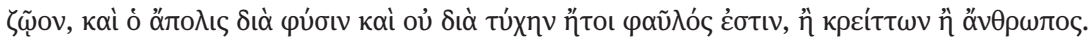

From these things therefore it is clear that the city-state is a natural growth, and that humans are by nature a political animal, and someone who is by nature and not merely by fortune citiless is either low in the scale of humanity or above it.

(Aristotle, Pol. 1253a 1-4)

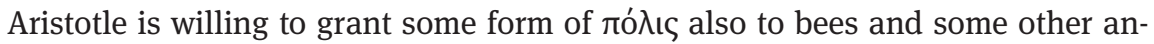
imals, but humans are "political" in a higher degree, and it is at this point that Aristole introduces the human possession of $\lambda$ óyos, which he have indicated already above. We now quote the passage in full, as not only humans' political nature but also, relatedly, their potential for justice and perception of good and evil are linked to $\lambda$ óyos, both speech and reason:

123 Aristotle, Pol. 1252b 9-16.

124 Aristotle, Pol. 1252b 19-26. Note in particular 25-26:

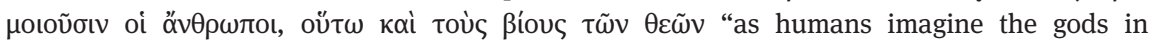
human form, so also they suppose their manner of life to be like their own".

125 Aristotle, Pol. 1252b 32-33 (oíov yò

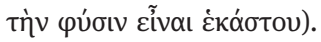

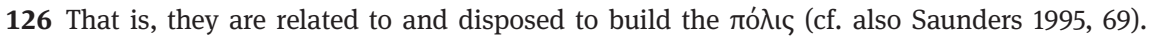




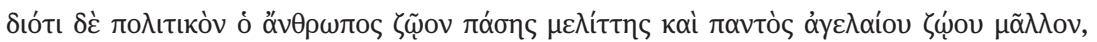

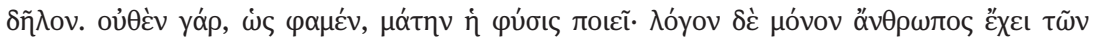

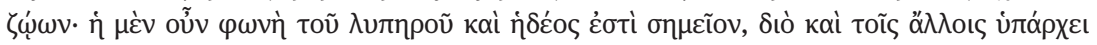

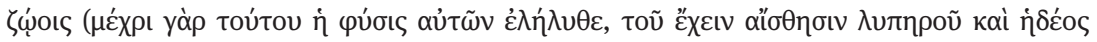

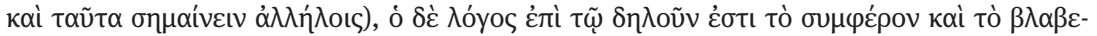

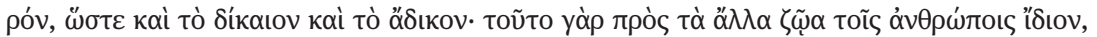

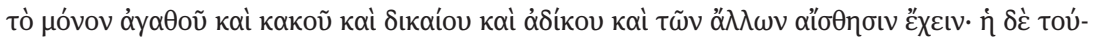

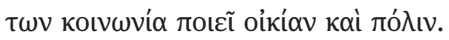

And why humans are a political animal in a greater measure than any bee or any gregarious animal is clear. For nature, as we declare, does nothing without purpose; and humans alone of the animals possess reason-and-speech ( $\lambda$ óyoc). ${ }^{127}$ The mere voice, it is true, can indicate pain and pleasure, and therefore is possessed by the other animals as well (for their nature has been developed so far as to have sensations of what is painful and pleasant and to signify those sensations to one another), but rational speech (入óyoc) is designed to indicate the advantageous and the harmful, and therefore also the right and the wrong; for it is the special property of humans in distinction from the other animals that they alone have perception of good and bad and right and wrong and the other moral qualities, and it is partnership in these things that makes a household and a city-state. (Aristotle, Pol. 1253a 7-18)

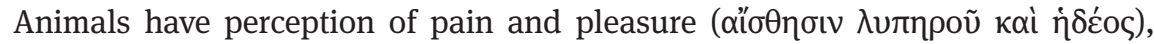
and have voice ( $\varphi \omega v \eta \dot{)}$ ) to communicate with respect to these sensations. They do not need more, and nature does not waste its gifts. Humans, however, do need more, not least for the life in the ró $\lambda$ ıs, and are therefore endowed with reason and articulate language. They need to be able to communicate about

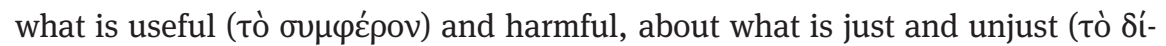

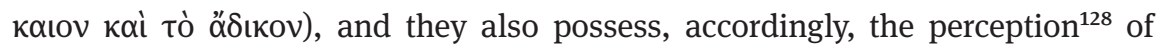

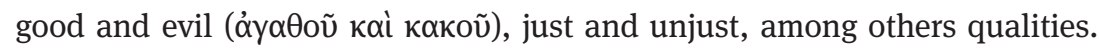

We see then in Aristotle's Politica a tendency to attribute many of the specifically human characteristics that pertain to the social sphere to their being en-

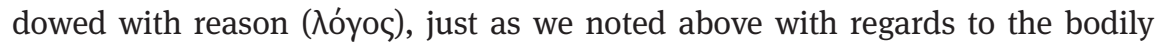
characteristics. ${ }^{129}$ The wider context of the statement which links humans'

127 We have adapted H. Rackham's translation, rendering $\lambda$ óyo not merely as "speech" but as "reason-and-speech", where it indicates the special capacity of human beings, and as "rational speech", where the utterances of humans are contrasted with the uses of voice in the case of animals. Cf. for the latter development of such distinctions Sextus Empiricus, AM 7.275-276 (

128 For an interpretation of "perception" as a shorthand for "a capacity to acquire that perception," see Saunders 1995, 70.

129 As already noted, Aristotle does not always use the lexeme $\lambda$ óyoৎ to make this point (other

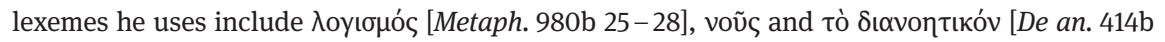
16-19], vónбıs [EN 1770a 15-16]). 


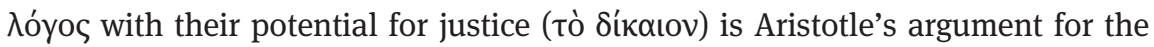

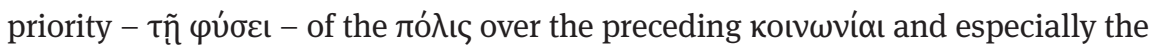
individual.

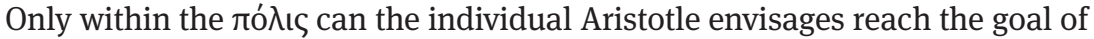

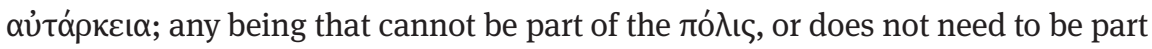

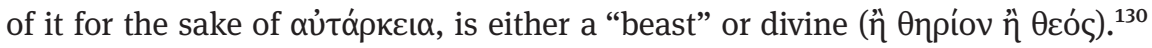

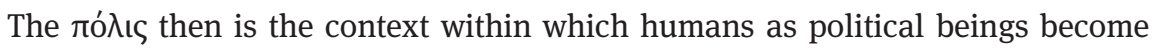

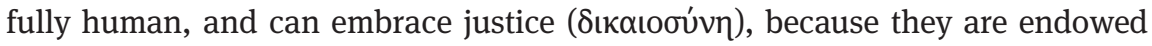

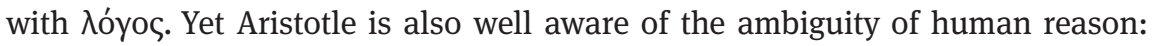
it can be oriented towards both good and evil, and accordingly humans may

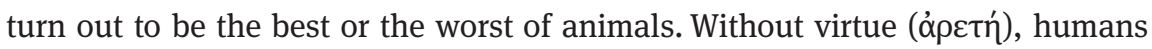
ultimately descend to the level of animals, ${ }^{131}$ which operate for Aristotle, as we have seen, on the level of pain and pleasure:

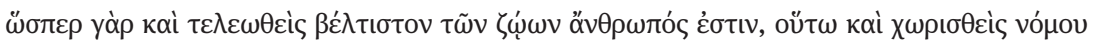

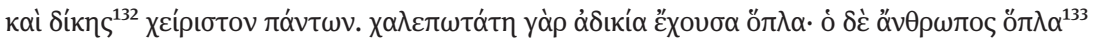

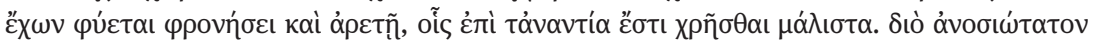

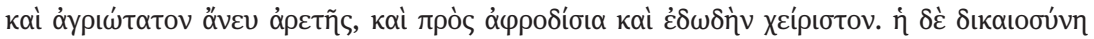

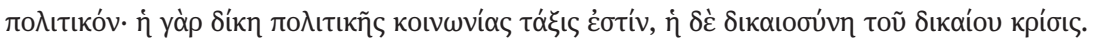

For as humans are the best of the animals when perfected, so they are the worst of all when sundered from law and justice. For unrighteousness is most pernicious when possessed of weapons, and humanity is born possessing weapons for the use of wisdom and virtue, which it is possible to employ entirely for the opposite ends. Hence when devoid of virtue humans are the most unscrupulous and savage of animals, and the worst in regard to sexual indulgence and gluttony. Justice on the other hand is an element of the state; for judicial procedure, which means the decision of what is just, is the regulation of the political partnership. (Aristotle, Pol. 1253a 32-39)

On the other hand, in his Ethica Nicomachea, Aristotle can associate the life according to the voũ with the divine sphere:

130 Aristotle, Pol. 1253a 26-28.

131 Cf. also e.g. Aristotle, EN 1145a 17, which assigns the label Onplótns to one of the traits that are to be avoided.

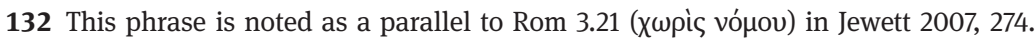

133 The ö $\pi \lambda \alpha$ in this passage are especially interesting with regards to Rom 6.13, a textual link that BDAG, s.v. ö $\pi \lambda$ ov, notes explicitly. Our discussion of the traditions contained in the myth of

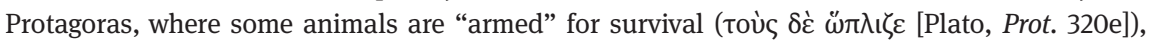
while humans are without natural (i.e. bodily) weapons (őo $\pi$ 入ov [Plato, Prot. 321c]), may suggest further resonances. 


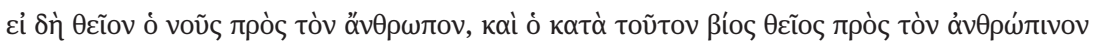
ßíov.

If then the intellect is something divine in comparison with human being, so is the life of the intellect divine in comparison with human life. (Aristotle, EN 1177b $30-31$ ) $^{134}$

The human mind is in any case for Aristotle the central defining property for what is distinctively human, both directly, and also in terms of the characteristic human marks that he associates with humans' endowment with reason. He is thus a pivotal figure in the larger story about how accounts of what it means to be human in ancient discourse increasingly revolve around human reason. For our purposes, another aspect is also crucial: Aristotle's emphasis on the necessary and constitutive social context of what it means to be human finds an obvious counterpart in the communities that Paul addresses with his communication.

\subsubsection{Stoic thinkers: Human reason as the basis for piety, freedom and justice}

In Stoic anthropology the difference between humans and animals is greatly emphasised. The crucial difference that elevates humans above animals is once

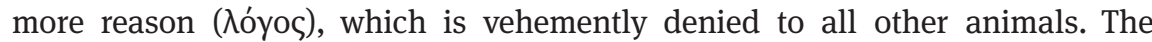
Stoic emphasis on this difference may be partly attributed to an ethical-protreptic concern that links humans' rational nature with the unique responsibility for an appropriate behaviour, and partly to their pronounced doctrine of providence, which assigns humans the first place with reason as the highest gift. ${ }^{135}$

What we noted already for Aristotle holds true for the Stoics as well, only more so: all the other human distinctives become associated with the central de-

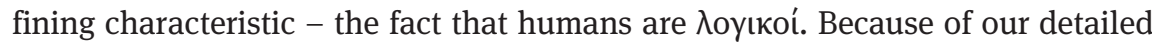
investigation of the Stoic material associated with the definition of human beings as rational animals in the previous chapter, and our detailed study of the Stoic Epictetus in the next chapter, we will not elaborate these points with reference to further Stoic texts here, but merely note central features associated with their being endowed with reason: (1) humans' relation to and knowledge of the

134 Translation H. Rackham, adapted. Cf. also EN 1177a 12-18. For the separation of the soul

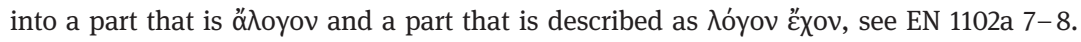

135 Cf. Dierauer 1977, 225. Dierauer's analysis is confirmed by the picture that has emerged in our investigation in the previous chapter, which has, as it to be expected, discussed some of the same texts. 
divine; (2) human creativity and freedom; (3) the human potential for justice and injustice, good and evil. ${ }^{136}$

The broader anthropological discourse we have charted in this chapter and the role of reason for being human is condensed in the Stoic definition of human

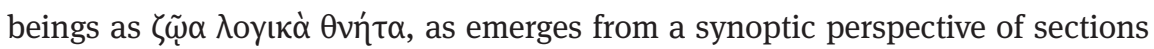
3.1 and 2.2. In the broader context of an increasing tendency in important segments of the Greco-Roman cultural encyclopaedia to associate specific religious, ethical and cultural marks of humanness with humans' endowment with reason,

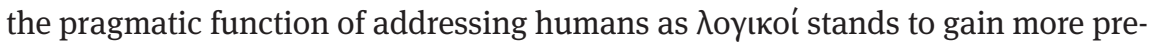
cise contours: by calling humans 入оуıко', the contexts of worship, justice, and cultural practice may be activated. Humans are thus addressed by that which makes them specifically human, distinguishes them from the other creatures, and unites them with the divine sphere, in order to summon them to what may be called the specifically human vocation.

\subsubsection{Conclusion}

We have put the Stoic definition of human beings as an endpoint of a development, in which increasingly what it means to be human is associated with their central distinguishing capacity, their endowment with reason. Though we cannot develop this here further, similar points could be made about later Platonic tradition, ${ }^{137}$ or with regards to Jewish-Hellenistic writings. However, as a fitting coda illustrating the broader relevance of the association of the definition of human beings with central distinguishing marks of genuine humanness, we will quote a short remark made by Plutarch, in which many of the themes we have seen associated with reason here in section 3.1 are connected to the definition of human beings which we have studied in section 2.2 (where we have not quoted this passage). ${ }^{138}$

In his treatise, Plutarch tells us that nature has implanted only a rudimentary form of love of offspring into the irrational animal, which is insufficient

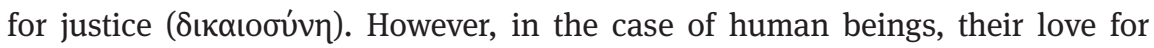

136 We may refer to the discussion in Dierauer 1977, 224-238, who elaborates this tendency with regard to six areas, noting important primary sources: (1) "Gotteserkenntnis und Gottesverwandtschaft”; (2) "Verhältnis zur Zeit”; (3) "Freiheit des Urteilens und Handelns"; (4) "Tugend und Schlechtigkeit”; (5) "Affekte”; (6) "Sprache".

137 See for instance, on Philo and the Timaeus the excellent treatment of Runia 1986. For the Platonic anthropology cf. van Kooten 2008.

138 Cf. however, Arius Didymus 2.7.6, which is similar. 
their children contains as seeds what she has introduced to human beings in view of their nature:

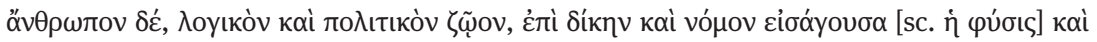

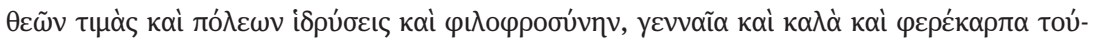

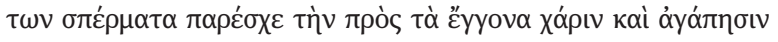

But in the case of humans, a rational and social animal, Nature, by introducing them to a conception of justice and law and to the worship of the gods and to the founding of cities and to human kindness, has furnished noble and beautiful and fruitful seeds of all these in the joy we have in our children and our love of them. (Plutarch, De amore prolis 495C) ${ }^{139}$

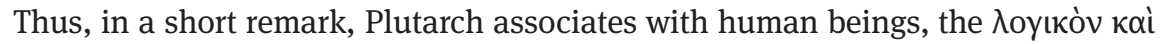
$\pi о \lambda ı \tau \iota \kappa o ̀ v ~ \zeta \tilde{\omega} о v$, their being introduced to justice, the law, the veneration of the gods, the building of cities, and kindness. With this we conclude our exploration into the centrality of the concept of reason for a discussion of what it means to be genuinely human in Greco-Roman tradition. We now turn to the idea of a human purpose in the cosmos and the language used for this.

\subsection{Language for a role of human beings in the cosmos}

Some ancient philosophers assume that human beings have a role to play in the cosmos. The conceptions differ in detail and the language varies, but there are general assumptions that many philosophers shared. And while explicit and thematic discussion is found mostly in philosophical texts, the idea belongs to Greco-Roman culture more broadly. We will see how Epictetus deploys this concept in chapter 4 and will argue that it is important for Paul in chapters 5-6.

An important early study of the topic of a human purpose in Greco-Roman context is Heinemann's Die Lehre von der Zweckbestimmung des Menschen. ${ }^{140}$ Since this topic has not enjoyed much scholarly attention, it will be useful to first develop the notion in dialogue with Heinemann's exposition. Our notion of a "human vocation" is developed from some of the same source texts that Hei-

139 Transl. W. C. Helmbold, adapted.

140 Heinemann 1926. He traced this idea even through Islamic and Jewish thinkers up to the medieval age. We are indebted to his work for several of the source texts we discuss or cite in this section. 
nemann discussed, though there is an important difference in our use of the term (see below). ${ }^{141}$

The question about the purpose of a particular being could be raised about any being (e.g. a pruning-knife ${ }^{142}$ ). But it is only in the case of a being capable of action that we could define its purpose to consist in some kind of action. Thus Heinemann first distinguishes between a passive destiny and an active purpose of a being. ${ }^{143}$ The idea of a human purpose in the active sense is thus the idea that there is some kind of action which is given as the goal of human striving. ${ }^{144}$ It implies that there is something that all humans beings should do, ${ }^{145}$ a task to be fulfilled, or as we will say a "vocation". This idea can be given as an answer to the question "what are we here for" or "to what purpose have we been made". As the latter formulation indicates, the idea of a human vocation presupposes that there is a power, someone or something which is responsible for the fact that human beings exist, that they are made the way they are and that the highest goal of human action accords with the goals or intention of this power. ${ }^{146}$ Clearly for monotheistic thinkers this is God, the creator. But these goals must also be such that human beings can know about them and understand them. ${ }^{147}$ Taken in this way these three conditions - belief in an ultimate "ought" for human beings, the intentionality of a metaphysical source, the recognisability of this intentionality ${ }^{148}$ - also correspond to three conditions that our heuristic notion of a "human vocation" must fulfil. But we differ in our application of a "human calling” from his notion of a "Zweckbestimmung des Menschen” insofar as we do not demand that the way in which the purposes of the power responsible for

141 Heinemann 1926 does not discuss Epictetus 1.16, which is a very clear example in which the idea of a human vocation is presupposed, used and presented.

142 Cf. Plato, Resp. 353a.

143 "Bestimmung ... im passiven Sinne" and "im aktiven Sinne” (Heinemann 1926, 4-5).

144 Heinemann defines the belief in a "Bestimmung des Menschen im aktiven ... Sinne" as "Der Glaube ..., dass ein bestimmtes - theoretisches oder praktisches - Verhalten uns als letztes Ziel unseres Strebens aufgegeben ist” $(1926,5)$.

145 It accepts that there is "ein Sollen, und zwar ein allgemein menschliches Sollen" (Heinemann 1926, 5).

146 The idea presupposes that what humans ought to do ("dies Sollen") is such that "es den Zielen derjenigen Macht entspricht, der wir unser Dasein und namentlich unsere eigentümliche Beschaffenheit verdanken" (Heinemann 1926, 5). Heinemann speaks of a "zielstrebig vorgestellte[r] Urgrun[d] für das Dasein und Sosein des Menschen”.

147 "Die Ziele dieses metaphysischen Urgrundes [müssen] uns Menschen durchsichtig und verständlich sein” (Heinemann 1926, 5).

148 Heinemann 1926, 5: "de[r] Glaub[e] an ein letztes Sollen, an einen metaphysischen Weltgrund, und an die Erkennbarkeit seiner Ziele”. 
human existence become known can in no way take recourse to "revelation."149 Paul's presentation of the idea of a human vocation is inflected by his eschatology and this leads to important differences from the philosophers. This does not, however, preclude Paul from interacting with the idea and the traditions in which it plays a role.

But this discussion does point to a major difference between Paul and some of these philosophical texts. While in the relevant philosophical texts, the task of human beings is based simply on the human inborn capacities (or the potential to develop them) and on the unchanging state of the cosmos, for Paul, due to his conception of eschatology, what he has come to see as the human task is shaped by an event within history, and the capacities on which the task is based are those of liberated human beings within a cosmos marked by a change brought about in the Christ event.

And yet this difference does not take away a fundamental similarity, if human beings are understood as beings endowed with reason. And if this is how they are made by the creator and if based on this there is a general shape of their vocation, then the new task for human beings in the inaugurated new age does not abolish the shape of their vocation, but fulfils it, given the new conditions.

We now look at several texts in which the idea can be found.

149 As Heinemann does when he qualifies the just quoted point about the transparency of the divine goals by excluding, by implication, the writings of the New Testament: "wenn es nicht nur, wie in der Bibel, zur Anerkennung einer offenbarten Aufgabe, sondern auch zu einer wissenschaftlich erörterten Lehre von unserer Bestimmung kommen soll” (Heinemann 1926, 5). Similarly, he stipulates that the content of the human task should be determined by reflection and not based on "naïve" reliance on authority ("[ein Sollen] dessen Inhalt - im Gegensatz zum naiven Autoritätsglauben - durch Reflexion ermittelt wird” [Heinemann 1926, 4]). When it comes to the Old Testament, Heinemann is willing to speak of a "Berufungslehre" but not of a "Zweckbestimmungslehre” (Heinemann 1926, 29), because for the sharper notion of Heinemann's "Zweckbestimmung" he requires that there be a step in which "aus dem Sein des Menschen auf sein Sollen [ge]schl[o]ßen [werden] muß” (29). Heinemann adds that this cannot and does not happen in Israel's scripture, because they suppose that our inborn inclinations may lead us away from God's will. Paul too describes human beings as de facto sinners, but the crucial point is that what humans should do does not derive from what they in fact do but what given how they are made (or redeemed) they could do. And if Paul shares the common view that human beings are endowed with reason, then it is possible that he builds on this an idea of a human calling. Heinemann $(1926,9)$ seems to distinguish a doctrine of a human task ("eine Lehre von der Aufgabe des Menschen") too sharply from a doctrine of human purpose (“Zweckbestimmungslehre”). 


\subsubsection{Aristotle's Protrepticus apud lamblichus}

The idea of a human calling is clearly expressed in Aristotle's Protrepticus, which was famous in the ancient world, but which has been lost and has to be reconstructed based on fragments. ${ }^{150}$ Many scholars have recognised that Iamblichus' Protrepticus (in chapters 5-12) ${ }^{151}$ makes use of Aristotle's lost works, including the Protrepticus. ${ }^{152}$ The details of the ascription to Aristotle are not decisive for our purposes, however, because we are not constructing a derivational argument. We are illustrating the constellation of ideas on which Paul could draw, as part of the Greco-Roman cultural encyclopedia.

In chapter 9 of Iamblichus' Protrepticus we find a clear expression of one version of the idea of a human vocation. ${ }^{153}$ Like the preceding chapters $(5-8)$,

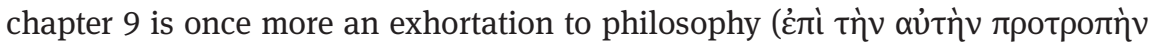
$\pi \rho о \chi \omega \rho о \tilde{\mu \varepsilon v ~[49.2]), ~ b u t ~ t h i s ~ t i m e ~ t h e ~ a r g u m e n t ~ p r o c e e d s ~ f r o m ~ t h e ~ " i n t e n t i o n ~ o f ~}$

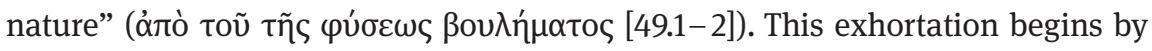
dividing all things and beings subject to change ( $\tau \tilde{\omega} v$ yıvo $\mu \varepsilon \dot{\varepsilon} \nu \omega v)$ into three

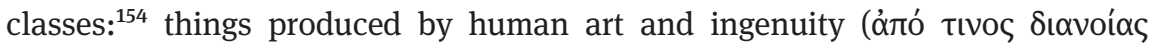

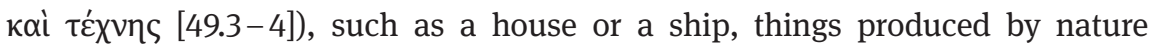

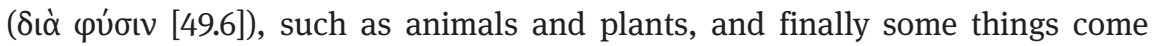

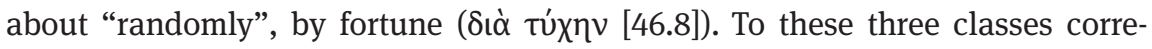
spond three different kinds of purpose (or lack thereof). Things produced by ac-

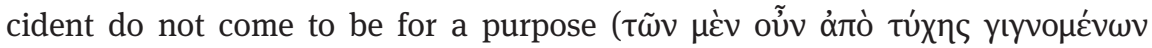

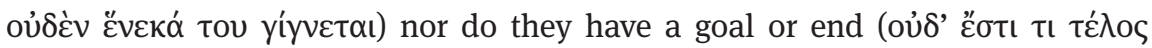

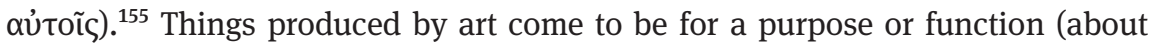
which their maker would inform you ${ }^{156}$ ) and they have a goal. ${ }^{157}$ In connection with products of art, the principle is stated that the end intended is always better than the product itself (49.15-16) because, for example, the goal of the art of medicine is health for the patient, while the outcome of a treatment often is not health.

150 Heinemann 1926, 7-10 discusses this passage as Aristotelian and as the earliest example. 151 For the Greek text we will use the edition of Pistelli, unless we indicate with a D that we cite the edition of Des Places. We will refer to the passages in Iamblichus' Protrepticus simply by page and line.

152 For a recent and brief overview on the reconstructions, see Brüllmann 2011.

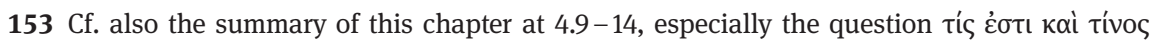

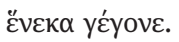

154 That these three categories are not exhaustive is indicated by 49.9-11.

155 49.11-12.

156 Cf. $49.14-15$.

$15749.13-14$ and 49.20-21. 
Finally, things produced by nature also come to be for a purpose (

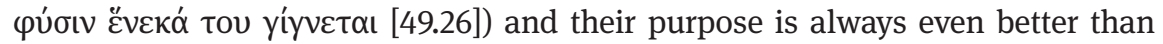
that of a product of art (49.25-27). The purposes for which products of nature come to be are superior to those of art (49.26-28), because art imitates ( $\mu$ เ nature and not vice versa (49.27-50.1). In fact, art exists only to support and

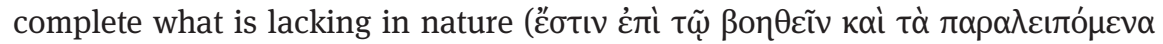

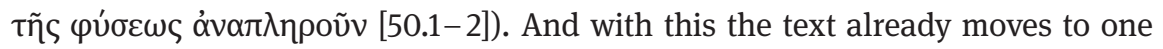
particular kind of being produced by nature, namely humans. Just like some seeds grow in any soil while others require the care of the farmer, ${ }^{158}$ so too human beings are, unlike other animals, not fully furnished by nature, but require the arts for their preservation. ${ }^{159}$ In any case, from the fact that art imitates nature, it follows that if products of art already come to be for a purpose, then a fortiori will the products of nature (50.12-14).

Now, in the case of humans, already their bodily parts have a function and purpose, for instance the eye-lid, which is not there in vain but so as to help the

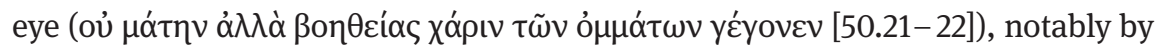
keeping stuff away that might otherwise fall into it. After a further distinction and a hint that animals that harm do not impede the overall argument, we finally arrive at the best of all earthly living beings, namely humans, which clearly are created according to nature:

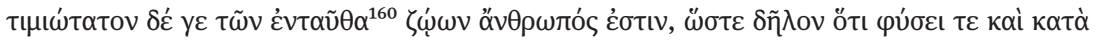

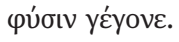

The worthiest of the beings living here below are humans, so that it is clear that they have come to be through nature and according to nature. $(51.4-6)^{161}$

As product of nature, humans were brought about for a purpose. What is it? Thus the question about the human vocation is raised explicitly:

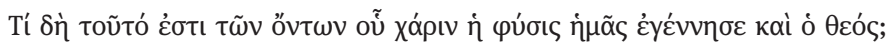

What then is it for the sake of which nature and God have brought us forth among the things that are? ${ }^{162}\left(81.11-12 \mathrm{D}^{163}\right)$

158 Cf. our discussion Epictetus 1.16 in section 4.4.

$15950.8-12$.

160 The addition is necessary, because for a Neoplatonist higher spirits are also living beings $(\zeta \tilde{\omega} \alpha)$.

161 Our translation.

162 Our translation.

163 Here we follow the text of Des Places, who follows a conjecture by Zuntz, which inserts $\tau i ́$

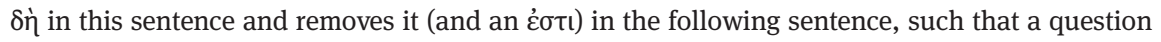


We have here all the elements for the notion of a human vocation: God or nature, a purpose for which humans are created, and some way, to be discussed shortly, in which this purpose, which consists in a certain behaviour, is based on how human beings are made.

The text lets Pythagoras answer the question: ${ }^{164}$ humans were made for the

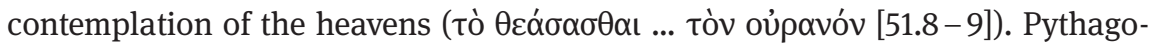

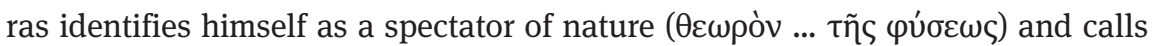

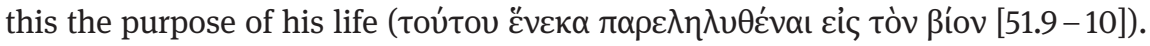

The reasons for the correctness of Pythagoras' answer are then given based on the principle that whatever is created last in a continuous development of a

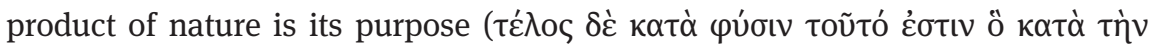

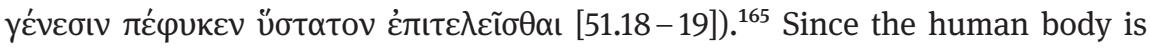
completed before the soul, and, within the soul, it is thinking which comes

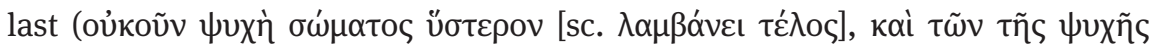

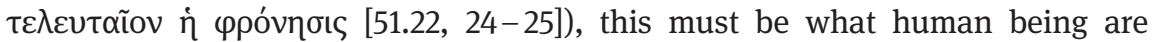

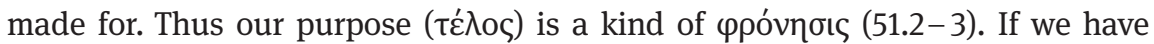

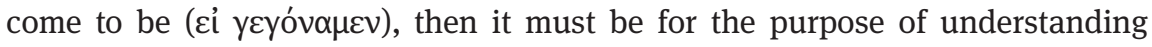

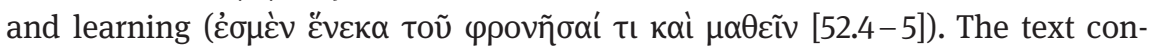
cludes that Pythagoras was right with his statement that every human being

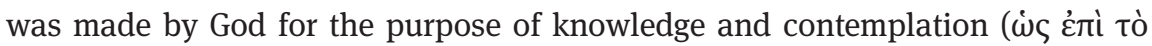

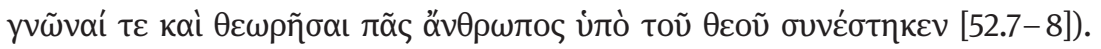

We have discussed this first example in detail, because it is a deliberate reflection on the human role within the cosmos. It shows the language used to speak about the human purpose within the cosmos and how that purpose is recognised in how human beings are made. While the language used here for the

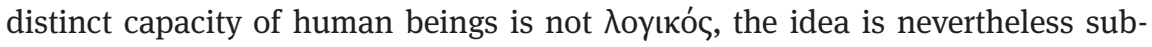

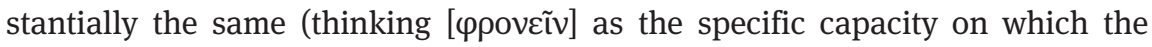
human purpose is based). This makes it possible to detect the language used to speak about a human vocation even where the discussion is not as elaborate and explicit. It is also significant that such a discussion about the human role in the cosmos occurs in protreptic speech (here an exhortation to philosophy). Once it is noted that Rom 12.1-2 also functions protreptically, this will support our reading that it is about the human vocation.

results, while Pistelli follows the manuscripts, even as the text remains slightly awkward without these changes.

164 And Anaxagoras follows suit.

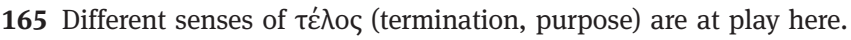




\subsubsection{Seneca: What you owe your nature}

We consider another example by the Roman Stoic Seneca. In one of his philosophical letters to Lucilius ${ }^{166}$ he writes:

For how will you know what behaviour should be cultivated unless you have discovered what is best for a human being, unless you have scrutinized his nature? You will only understand what you must do and what you must avoid when you have learned what you owe to your nature (quid naturae tuae debeas). (Seneca, Ep. 123.3) ${ }^{167}$

The natura in question is of course the specifically human rational nature, ${ }^{168}$ as we see in another letter:

For as man is a reasoning creature (rationale enim animal est homo), so his goodness is complete if it has fulfilled the purpose for which he was born (bonum eius, si id inplevit cui nascitur). And what is it that reason (ratio) demands from him? A very easy thing: to live according to his nature (secundum naturam suam vivere). (Seneca, Ep. 41.8)

As for Epictetus, so also for Seneca the human endowment with reason is what marks out what is truly human (in the context the opinion is presented as from a diatribal interlocutor, but the relevant premise is shared also by Seneca):

You are saying that every animal is first adjusted to its own composition, but that the composition of a human is rational (hominis autem constitutionem rationalem esse), and so a person is adjusted to himself as a rational being (tamquam rationali) and not like an animal; for a person is dear to himself in that part which makes him human (ea enim parte sibi carus est homo qua homo est). (Seneca, Ep. 121.14)

Here reason is what makes humans human and that is why their human vocation is based on it. Thus here the idea is that a being's purpose is founded upon that which makes it distinct (where in the Protrepticus it was that which was completed last).

166 For a recent commentary see Inwood 2007.

167 The translations in this section follow Fantham 2010.

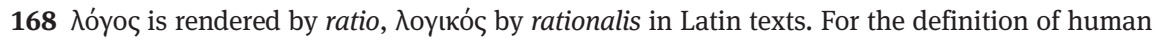
beings cf. e.g. Quintillian, Institutio oratoria 5.6.56. 


\subsubsection{Other examples}

Having discussed two examples in detail, it will suffice to catalogue further examples briefly. ${ }^{169}$ These examples illustrate some of the language that is used to speak about a human role in the cosmos and that this idea is widespread among ancient thinkers (even if there is no mention of $\lambda$ oyıкós). In a first class of cases,

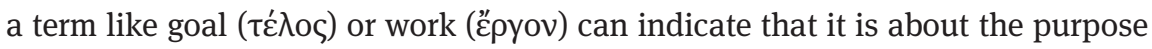
of human beings. Thus, for instance:

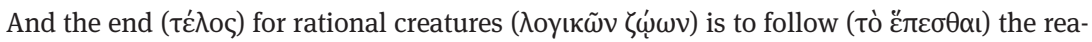
son ( $\lambda$ ó $(\omega)$ and the rule of that most venerable archetype of a governing state - the Universe. (Marcus Aurelius 2.16.1) ${ }^{170}$

The second class consists in variations of "being born for something". The third class adopts the perspective of God or nature bringing human beings into the cosmos. All three of these are present in the following passage of Marcus Aurelius:

At break of day, when you are reluctant to get up, have this thought ready to mind: "I am

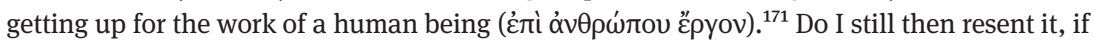

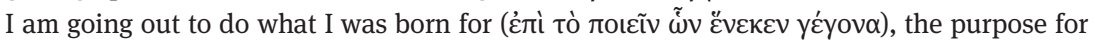

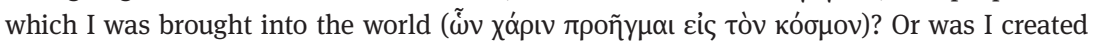

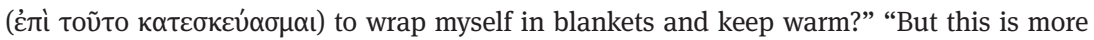

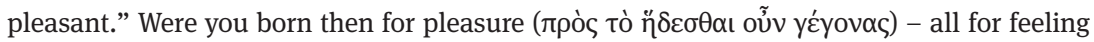

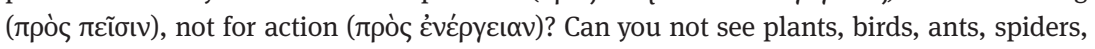

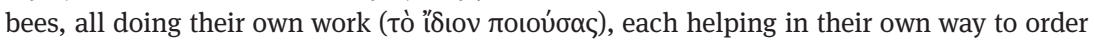

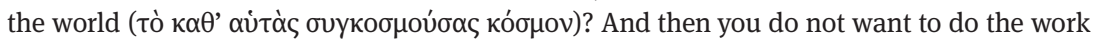

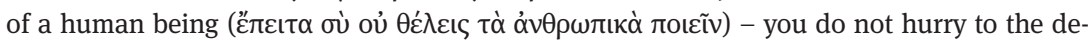

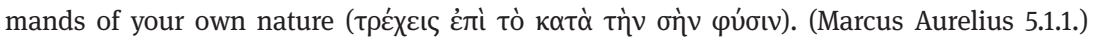

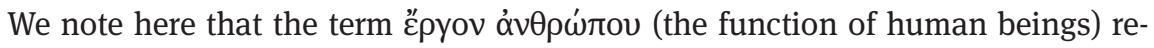
calls Aristotle's function argument in the Nicomachean Ethics, in which the specific capacity of a being is what determines its purpose. ${ }^{172}$ This is why it also features in the following passage by the philosopher Aspasius (1st half of the 2nd

169 Many of these examples (and more) are discussed in Heinemann 1926. We are less focused on establishing chronology or ascriptions to earlier Stoics and simply seek to document the variety of language used to describe that human beings have a purpose and in what it consists. 170 Transl. M. Hammond for Marcus Aurelius, adapted. (We have quoted this passage already in section 2.2.)

171 The term हैpyov is important for Epictetus 1.16 (see section 4.4.2).

172 EN 1097b 22-1098a 20. See also section 4.2. 
century AD), which comments upon that passage of Aristotle, and explains it by

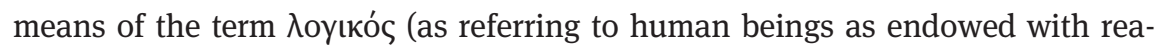
son), which was not yet used in this sense by Aristotle. ${ }^{173}$

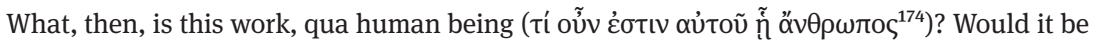

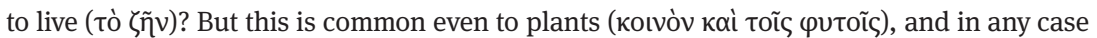
it is not his work to have a share in life: this, rather, belongs to him by nature. If living then

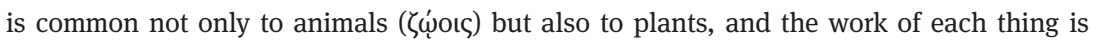

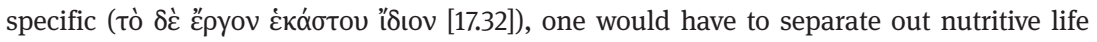

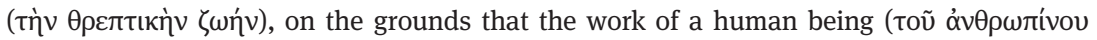
हैpyou) does not reside in this. Similarly, neither would it reside in growth-related life ( $\tau \tilde{n}$ $\alpha \cup 3 \xi \eta \tau \leftarrow \kappa n ̃)$, for this too is common to plants. But nor again would it reside in perceptive

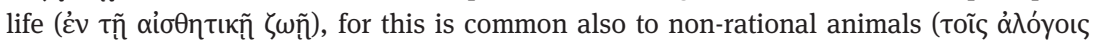
$\zeta \dot{\omega}$ orc). The productive and rational life, then, is left to be the work of a human being ( $\lambda \varepsilon^{i}-$

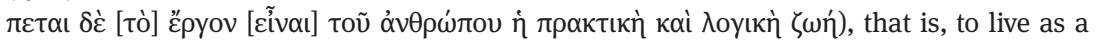

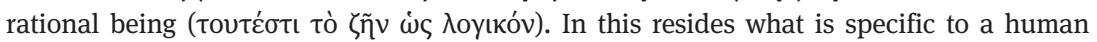

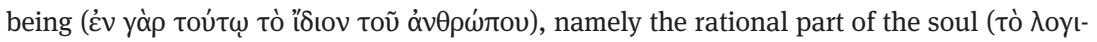

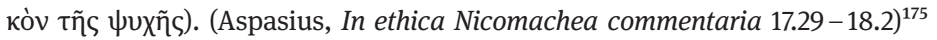

The next examples are variations of "being born for something”, the second class, which appears in such formulations as ortus est ad contemplandum, hom-

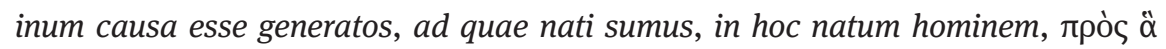

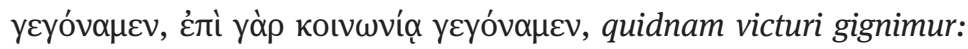

Humans themselves however came into existence for the purpose of contemplating and imitating the world (ipse autem homo ortus est ad mundum contemplandum et imitandum). (Cicero, ND 2.37) $)^{176}$

Sed quoniam, ut praeclare scriptum est a Platone, non nobis solum nati sumus ortusque nostri partem patria vindicat, partem amici, atque, ut placet Stoicis, quae in terris gignantur, ad usum hominum omnia creari, homines autem hominum causa esse generatos, ut ipsi inter se aliis alii prodesse possent, ${ }^{177}$ in hoc naturam debemus ducem sequi, ${ }^{178}$ communes utilitates in medium afferre mutatione officiorum, dando accipiendo, tum artibus, tum opera, tum facultatibus devincire hominum inter homines societatem.

173 As we have seen in section 2.2.6.3.3.

174 हैpyov is to be supplied from context.

175 This passage is not discussed by Heinemann, but it is important for our reading of Epictetus. We already quoted this passage in section 2.2.6.3.3, but it is worth recalling here in the context of other vocational language. Transl. Konstan 2006.

176 Transl. H. Rackham. We have quoted this passage already and pointed out the two-part structure of the human role in the cosmos.

177 Cf. the similar point Cicero makes (using the language of natos ad) at Tusc. 1.32.

178 Cf. the language of $\check{\pi} \pi \varepsilon \sigma \theta \alpha$ in Marcus Aurelius 2.16 quoted above. 
But since, as Plato has admirably expressed it, we are not born for ourselves alone, but our country claims a share of our being, and our friends a share; and since, as the Stoics hold, everything that the earth produces is created for humans' use; and as humans, too, are born for the sake of humans, that they may be able mutually to help one another; in this direction we ought to follow Nature as our guide, to contribute to the general good by an interchange of acts of kindness, by giving and receiving, and thus by our skill, our industry, and our talents to cement human society more closely together, human to human. (Cicero, Off. 1.22) $)^{179}$

Prima illa commendatio, quae a natura nostri facta est nobis, incerta et obscura est, primusque appetitus ille animi tantum agit, ut salvi atque integri esse possimus. Cum autem dispicere coepimus et sentire quid simus et quid <ab>animantibus ceteris differamus, tum ea sequi incipimus, ad quae nati sumus.

The earliest feeling of attraction which nature has created in us towards ourselves is vague and obscure, and the earliest instinct of appetition only strives to secure our safety and freedom from injury. When, however, we begin to look about us and to perceive what we are and how we differ from the rest of living creatures, we then commence to pursue the objects for which we are intended by nature. (Cicero, Fin. 5.41) ${ }^{180}$

Habebat perfectum animum et ad summam sui adductum, supra quam nihil est nisi mens dei, ex quo pars et in hoc pectus mortale defluxit; quod numquam magis divinum est quam ubi mortalitatem suam cogitat et scit in hoc natum hominem, ut vita defungeretur, nec domum esse hoc corpus sed hospitium, et quidem breve hospitium, quod relinquendum est ubi te gravem esse hospiti videas.

He possessed perfection of soul, developed to its highest capabilities, inferior only to the mind of God - from whom a part flows down even into this heart of a mortal. But this heart is never more divine than when it reflects upon its mortality, and understands that man was born for the purpose of fulfilling his life, and that the body is not a permanent dwelling, but a sort of inn (with a brief sojourn at that) which is to be left behind when one perceives that one is a burden to the host. (Seneca, Ep. 120.14) $)^{181}$

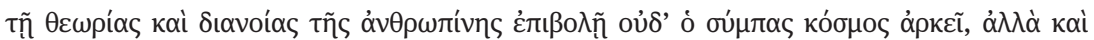

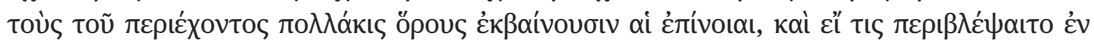

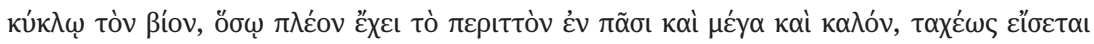

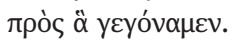

The whole universe is not enough to satisfy the speculative intelligence of human thought; our ideas often pass beyond the limits that confine us. Look at life from all sides and see how in all things the extraordinary, the great, the beautiful stand supreme, and you will soon realize what we were born for.

(Pseudo-Longinus [1st half of the 1st century AD], De sublimitate 35.3$)^{182}$

179 Transl. Walter Miller, adapted.

180 Transl. H. Rackham.

181 Cf. Heinemann 1926, 19. Note that defungi refers to more than simply death. Transl. Richard M. Gummere.

182 Transl. W. Hamilton Fyfe and Donald Russell. 


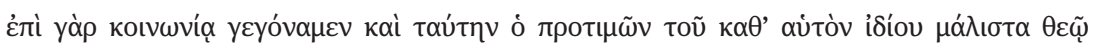

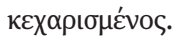

For we are born for fellowship, and he who sets its claims above his private interests is specially acceptable to God. (Josephus, C. Ap. 2.195) (183 $^{13}$

The next passage, from the Satirical poet Persius Flaccus, who lived in the Neronic period, still features language of "being born for something" (quid sumus et quidnam victuri gignimur), but also already features language of the third class quem te deus esse iussit, et humana qua parte locatus es in re.

Is there something you're heading for, a target for your bow (est aliquid quo tendis et in quod derigis arcum)? Or are you taking pot shots at crows with bricks and clods of mud, not caring where your feet take you? Is your life an improvisation? ... Learn, you idiotic creatures, discover the rationale of existence (discite et, o miseri, causas cognoscite rerum): What are we and what sort of life are we born for (quid sumus et quidnam victuri gignimur)? ... What role is assigned (ordo quis datus) you by God and where in the human world have you been stationed (quem te deus esse iussit et humana qua parte locatus es in re)? (Persius Flaccus $3.60-62,66-68,71-72)^{184}$

Further examples speak of human beings introduced into the world in a certain

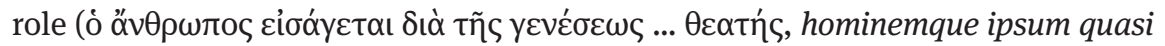
contemplatorem caeli) or being created for something:

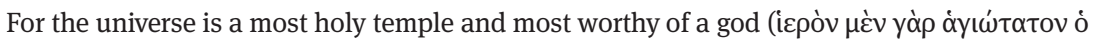

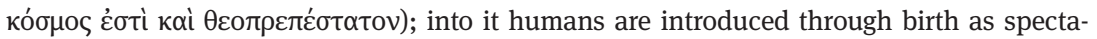

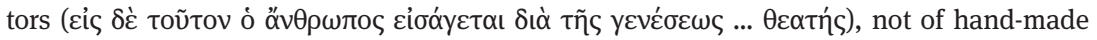

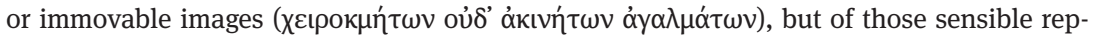
resentations of knowable things that the divine mind, says Plato, has revealed (oĩ $\alpha$ voũ

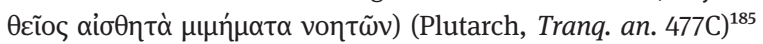

... and humanity itself formed as it were to observe the heavens and worship the gods ${ }^{186}$ (hominemque ipsum quasi contemplatorem caeli ac deorum cultorem), and lastly all fields and seas made subject to the service of human beings - when then we behold all these things and countless others, can we doubt that some being is over them, or some author, (praesit aliquis vel effector) ... some governor of so stupendous a work of construction (moderator tanti operis et muneris)? (Cicero, Tusc. 1.69) ${ }^{187}$

183 Transl. H. St. J. Thackeray. Cf. also Epictetus, frag. 1 (Schenkl).

184 Transl. Susanna Morton Braund, adapted.

185 Transl. W. C. Helmbold. Note the formulation in Epictetus 1.6.19 (section 4.5).

186 Against J. E. King's translation we have kept deorum with the manuscript evidence (against the conjecture terrarum).

187 Transl. J. E. King, adapted (with a different reading). Note also the "natural theology" passage that follows in context ut deum agnoscis ex operibus eius "that you recognise God from his 


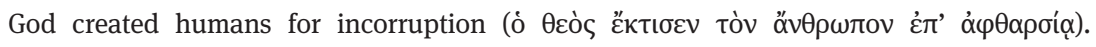
(Wis 2.23)

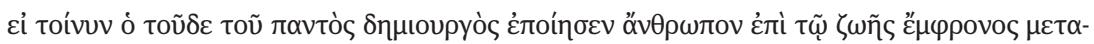

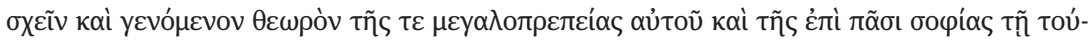

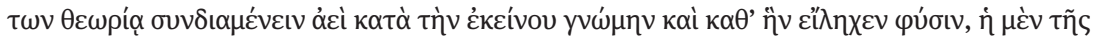

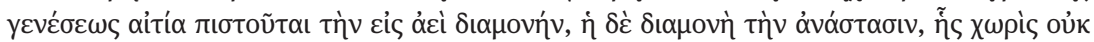

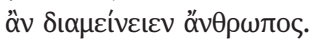

So if the creator of the universe has made humans for sharing in a life of understanding, and having become spectators of his grandeur and wisdom in all things by their contemplation, to remain with him for ever, according to his intention, in view of which he had alloted (their) nature, then the cause for which they were made proves their perdurance for ever, and their perdurance their resurrection, without which human beings would probably not perdure. (Athenagoras, De resurrectione 13.2) ${ }^{188}$

This list shows the variety of language than can be used to describe the purpose of human beings and in what it consists. Many of the descriptions of the human vocation feature contemplation and action which corresponds to it, which will be important in Epictetus and Paul, as we shall see.

\subsection{Conclusion}

We have thus offered a broader contextualisation for the role of reason in GrecoRoman reflections on what it means to be human. The Stoic definition of human beings as $\theta v \eta \tau \dot{\alpha} \lambda$ oyık $\grave{\zeta} \zeta \tilde{\omega} \alpha$ marks an endpoint of a development, in which what it means to be human is increasingly associated with their central distinguishing capacity, their endowment with reason.

We have further developed the notion of a human vocation in conversation with Heinemann and illustrated the language that is used in ancient sources to speak about a human role in the cosmos, which is based on their distinct capacity, namely their being endowed with reason.

This sets us up for our discussion of Epictetus in the next chapter, where we

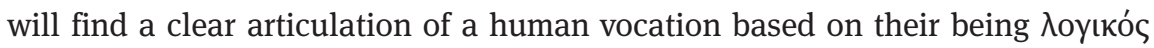
and where many of the themes, motifs and language we surveyed in this chapter will reappear.

works”. This passage is cited by Käsemann 1980, 36, but he does not consider the parallel in a vocational context.

188 Our translation. Cf. also, for language of purpose, Athenagoras, De resurrectione 12. 